\title{
Geochronology of granites of the western Korosten AMCG complex (Ukrainian Shield): implications for the emplacement history and origin of miarolitic pegmatites
}

\author{
Leonid Shumlyanskyy ${ }^{1}$, Gerhard Franz ${ }^{2}$, Sarah Glynn ${ }^{3,4}$, Oleksandr Mytrokhyn ${ }^{5}$, Dmytro Voznyak ${ }^{6}$, \\ and Olena Bilan ${ }^{5}$ \\ ${ }^{1}$ School of Earth and Planetary Sciences, Curtin University, GPO Box U1987, Perth WA 6845, Australia \\ ${ }^{2}$ Department of Applied Geochemistry, Technische Universität Berlin, \\ Ernst-Reuter-Platz 1, 10587 Berlin, Germany \\ ${ }^{3}$ School of Geosciences, University of the Witwatersrand, 1 Jan Smuts Avenue, Johannesburg, South Africa \\ ${ }^{4}$ GFZ German Research Centre for Geosciences, Telegrafenberg, 14473 Potsdam, Germany \\ ${ }^{5}$ Institute of Geology, Kyiv Taras Shevchenko National University, Vasylkivska St., 90, 03022 Kyiv, Ukraine \\ ${ }^{6}$ M.P. Semenenko Institute of Geochemistry, Mineralogy and Ore Formation of the NAS of Ukraine, \\ Kyiv, Palladin Ave., 34, Ukraine
}

Correspondence: Leonid Shumlyanskyy (leonid.shumlyanskyy@ curtin.edu.au) and Gerhard Franz (gerhard.franz@tu-berlin.de)

Received: 22 July 2021 - Revised: 27 September 2021 - Accepted: 3 October 2021 - Published: 11 November 2021

\begin{abstract}
The origin of large miarolitic (also known as "chamber") pegmatites is not fully understood although they may have great economic value. The formation of cavities in magmatic bodies is related to melt degassing and gas or fluid flow through partially solidified magma. In this paper, the origin of the Volyn pegmatite field, located in the Palaeoproterozoic Korosten anorthosite-mangerite-charnockite-granite (AMCG) complex, NorthWestern region of the Ukrainian Shield, is discussed. Pegmatites of the field host deposits of piezoelectric quartz that is accompanied by gem-quality beryl and topaz. The Volyn pegmatite field is confined to granites located in the south-western part of the Korosten complex and extends for $22 \mathrm{~km}$ along the contact with the anorthosite massif within the Korosten plutonic complex. Geological data indicate hybridization of basic melts and partly crystallized granites, as well as direct impact of fluids derived from basic melts on the chamber pegmatites.

The new U-Pb zircon ages obtained for granites and pegmatites of the Korosten complex confirm that the rock assemblage in the northern part of the complex crystallized between 1800 and $1780 \mathrm{Ma}$, whereas rocks in the southern part intruded mainly between 1768 and $1755 \mathrm{Ma}$. U-Pb zircon ages for granites from the south-western part of the Korosten complex indicate that granites were emplaced at 1770-1765 Ma, a few million years prior to the intrusion of the gabbro-anorthosite massif (1762-1758 Ma), while chamber pegmatites in these granites crystallized at $1760 \pm 3 \mathrm{Ma}$, coevally with the basic rocks. Ultimately, the formation of the chamber pegmatites was related to the reheating of the semi-crystallized granitic intrusion and to fluids migrating from the underlying gabbro-anorthosite massif.
\end{abstract}




\section{Introduction}

Miarolitic (also known as "chamber") pegmatites differ from other types of pegmatites by the presence of empty cavities that enable the free growth of well-formed giant crystals of various minerals (e.g. Lazarenko et al., 1973; Zito and Hanson, 2014; Phelps et al., 2020) that may have great economic value. The sizes of miarolitic cavities are quite variable, but commonly they do not exceed centimetres or decimetres. Their occurrence indicates the process of melt degassing and gas/fluid flow through partially solidified magma (e.g. Candela and Blevin, 1995; Thomas et al., 2009; Peretyazhko, 2010; Vigneresse, 2015; Pistone et al., 2020). Large cavities, reaching sizes ranging from tens to hundreds of cubic metres, are extremely rare in nature, and their formation requires special conditions, such as the gas/fluid filling the cavity must be able to overcome the lithostatic pressure.

In this communication, the results of $\mathrm{U}-\mathrm{Pb}$ dating of zircon from granites that were sampled in the western part of the Korosten anorthosite-mangerite-charnockite-granite (AMCG) plutonic complex and from a miarolitic (chamber) pegmatite representing the Volyn pegmatite field are reported. In addition, we report the results of $\mathrm{Hf}$ isotope studies in zircon from the same samples, as well as four specimens representing hybrid and granite rocks of the Korosten complex. All these data are discussed in the context of the magmatic evolution of the Korosten plutonic complex (KPC) and the formation of the Volyn pegmatite field.

\section{Geological setting}

\subsection{Korosten plutonic complex}

The Korosten plutonic complex occurs in the North-Western region of the Ukrainian Shield, in proximity to the junction zone between Sarmatia and Fennoscandia. It is relatively well exposed, being only partly covered by recent sediments. The KPC is one of the largest (about $10400 \mathrm{~km}^{2}$ ) AMCG complexes in the world (Fig. 1). Granites occupy about $75 \%$ of the complex, while the rest is dominated by basic rocks. The host rocks are Palaeoproterozoic gneisses, granites, and migmatites (Stepanyuk et al., 2000; Shcherbak et al., 2008; Shumlyanskyy et al., 2018b). Remnants of the platformal cover represented by quartzites and slates occur as large xenoliths among the rocks of the KPC and represent its ancient roof. Their presence indicates a relatively high level of intrusion and limited subsequent erosion not exceeding $1000 \mathrm{~m}$. The same rocks can be found to the northwest of the KPC, in the Bilokorovychi graben syncline filled with platformal sediments, deposited before the KPC formation (Shumlyanskyy and Mazur, 2010). In its northern part, volcanic rocks coeval with the KPC and slightly younger terrigenous rocks fill the Ovruch basin and partly cover the KPC

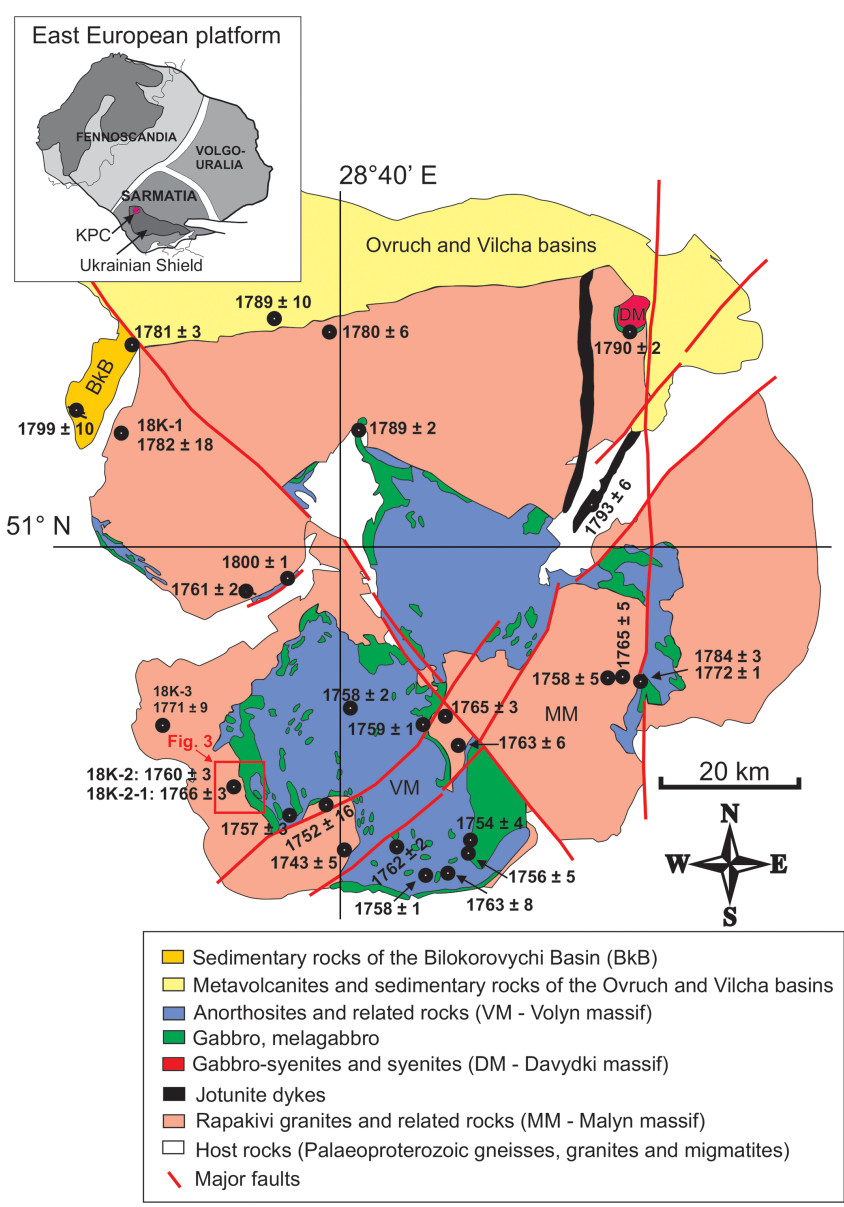

Figure 1. Sketch map of the Korosten plutonic complex (KPC) with locations of dated samples and ages (in Ma; with additions, based on Shumlyanskyy et al., 2017).

(Shumlyanskyy and Bogdanova, 2009; Shumlyanskyy et al., 2015b).

The KPC encompasses rapakivi granitoids and a suite of basic rocks that includes predominantly anorthosite and leucogabbronorite, as well as subordinate gabbroic rocks. Monzonites and syenites are volumetrically minor rock types. Anorthosites and related rocks form sheet-like bodies, the largest of which is the Volyn massif that occupies $1250 \mathrm{~km}^{2}$ and varies in thickness from hundreds to thousands of metres. The gabbroic series includes various rocks from leucogabbro to melagabbro and ultramafics that form layered intrusions and sheet-like bodies in association with the anorthosite massifs. Ferromonzodiorite and quartzferromonzodiorite dykes are widespread in the KPC, where they cut both the basic and felsic rocks, as well as intrude on the host rocks of the complex (Duchesne et al., 2017; Shumlyanskyy et al., 2018a).

Medium-grained granites with sparse mantled ovoids are the dominant rocks at the current level of erosion, whereas coarse-grained wiborgitic rapakivi is a rare rock 
type. Biotite-amphibole granites with fayalite and $\mathrm{Fe}$ hedenbergite prevail near the contacts with the basic rocks. Towards the central parts of the granitic massifs, these rocks turn into biotite-amphibole granite. The contacts of the gabbroic massifs with rapakivi granites are complicated and indicate the emplacement of basic melts into a partly crystallized granite chamber, resulting in mingling and hybridization (Mitrokhin and Bilan, 2014). The lines of evidence for these processes include the following: sinuous branching veins of fayalite-hedenbergite syenite observed in gabbro; discontinuous chilled margins occurring in gabbro but absent in granites; mafic inclusions in granites having pillow-like morphology and chilled margins; and alkali feldspar ovoid phenocrysts occurring in gabbro (Fig. 2). The structure of the hybrid rocks varies from massive to taxitic, banded, or network-like.

From the very first geological studies of the KPC, the question of the temporal relationships between basic and felsic rocks has remained as one of the most controversial. Tarasenko (1895) argued for a younger age of basic rocks with respect to granites, whereas Sobolev (1947) presented a model in which the emplacement and crystallization of the basic melt were accompanied by melting of the crustal rocks, giving rise to granite formation. Both basic and felsic rocks are virtually coeval and may have been emplaced in several pulses. Although this model is generally accepted (e.g. Mitrokhin et al., 2008; Shumlyanskyy et al., 2017), there is still a widespread opinion that rapakivi granites cropping out at the modern surface are slightly younger than basic rocks (e.g. Lichak, 1983).

\subsection{Geological structure of the Volyn pegmatite field}

The Volyn pegmatite field is confined to granites located in the south-western part of the KPC, extending for $22 \mathrm{~km}$ along the contact with the anorthosite massif, while the width of the field varies between 300 and $1500 \mathrm{~m}$ (Fig. 3; Lazarenko et al., 1973, Lichak, 1983). Pegmatite-bearing granites are variable in composition, texture, and structure. They contain small ovoids of feldspars surrounded by an aplitic to granophyric matrix. Alkali feldspars (perthitic orthoclase and microcline) noticeably prevail over quartz and oligoclase. Mafic minerals are extremely ferrous, and hastingsite hornblende and annite are the most abundant mafic minerals. Fayalite, Fe-hedenbergite, Fe-actinolite, grunerite, and iddingsite are present in minor amounts. Accessories are ilmenite, zircon, apatite, fluorite, and allanite.

Several zones can be distinguished across the pegmatite field, starting from the contact with basic rocks towards the inner parts of the granite massif: zones with (1) pegmatite veinlets, (2) fully differentiated chamber pegmatites, (3) disseminated small pegmatite bodies, and (4) quartz veinlets surrounded by leaching zones (Lichak and Tsarovskiy, 1957). The pegmatite bodies are unevenly distributed and form chains, rings, or equant groups. They are not intercon- nected, have no obvious feeders, and occur as isolated bodies. According to Marakushev et al. (1989), pegmatite bodies in the Volyn field either occur at the places of their segregation or have moved upward for a short distance. They are variable in shape and size, but all have a similar internal construction. Each pegmatite body has the outermost zone of graphic pegmatite that turns inwards into the pegmatoid zone. The central parts of the largest bodies contain a cavity that can reach tens to hundreds of cubic metres in size, above which quartz and block feldspar zones are located. Below the cavity, a leaching zone composed of albitized potassium feldspar usually occurs.

The pegmatites were mined for quartz (as raw material for piezoelectric quartz), which occurs in metre-sized crystals weighing tons (Lyckberg et al., 2009, and references therein). The locality is known for gem-quality beryl crystals of the colour variety heliodor and large amounts of topaz that have also been mined. Another peculiarity is the occurrence of organic matter known as "kerite" (Franz et al., 2017, and references therein) for which the age of pegmatite formation represents the upper age limit.

Marakushev et al. (1989) also described zones of mafic mineral enrichment in the host granites that accompany each pegmatite body. The size of such zones correlates with the size of the pegmatite body. The amount of mafic minerals varies from $15 \mathrm{vol} \%$ to $50 \mathrm{vol} \%$ or more. In contrast to the ovoid texture of the host granite, melanocratic zones contain euhedral zoned plagioclase. The core parts of plagioclase are composed of andesine $\left(\mathrm{An}_{34-30}\right)$, whereas the outer parts are composed of oligoclase $\left(\mathrm{An}_{26-20}\right)$, both being more calcic than plagioclase in the host granite. The main mafic mineral is biotite, while amphibole may occur at some distance from the pegmatites. Olivine and pyroxene are also present in minor amounts. Such zones of mafic mineral enrichment occur immediately below the pegmatite bodies and, rarely, may also surround them. Enrichment in ilmenite and zircon in the host rocks has also been reported by Ivantyshyn et al. (1957).

Host granites contain areas of micropegmatite or graphic textures that were described as incipient pegmatite. In addition, granites contain accessory minerals typical of pegmatite bodies, such as black quartz (morion), fluorite, topaz, and ferriferous micas, among others. Lichak (1983) emphasized that pegmatite bodies are cognate to their host granites and often reveal gradual contacts.

Based on the results of studies of primary fluid inclusions in the outer zones of beryl crystals, Vozniak et al. (2012) defined $P-T$ (pressure and temperature) parameters for the intermediate to late stages of pegmatite crystallization as 190 $200^{\circ} \mathrm{C}$ and $10-13 \mathrm{MPa}$ (corresponding to depths of 1000 $1300 \mathrm{~m}$ ). Vozniak (2007) also used the "chemical dating method" (based on the measurements of $\mathrm{U}, \mathrm{Th}$, and $\mathrm{Pb}$ concentrations) applied to zircon and uraninite inclusions in topaz to demonstrate that pegmatites crystallized at ca. $1750 \mathrm{Ma}$. 

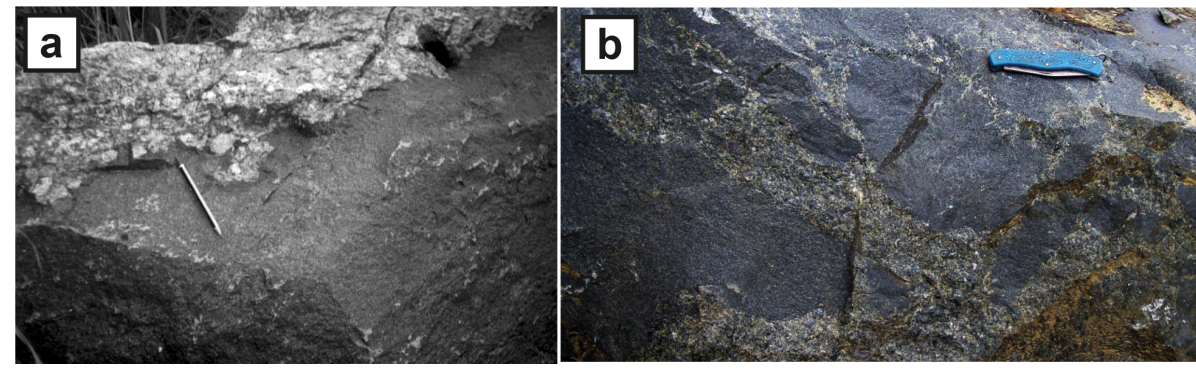

Figure 2. Photographs demonstrating field relationships between basic rocks and granites. (a) Convoluted contact between ovoid granite (upper part, light-grey) and monzogabbro (dark-grey); small open pit at the right bank of the river Dobrynka between the villages of Buky and Dobryn. Pen for scale is ca. $15 \mathrm{~cm}$. (b) Mafic magmatic enclaves in rapakivi granite; open pit at the right bank of the river Dobrynka between the villages of Buky and Dobryn. Knife for scale is $8 \mathrm{~cm}$ long.

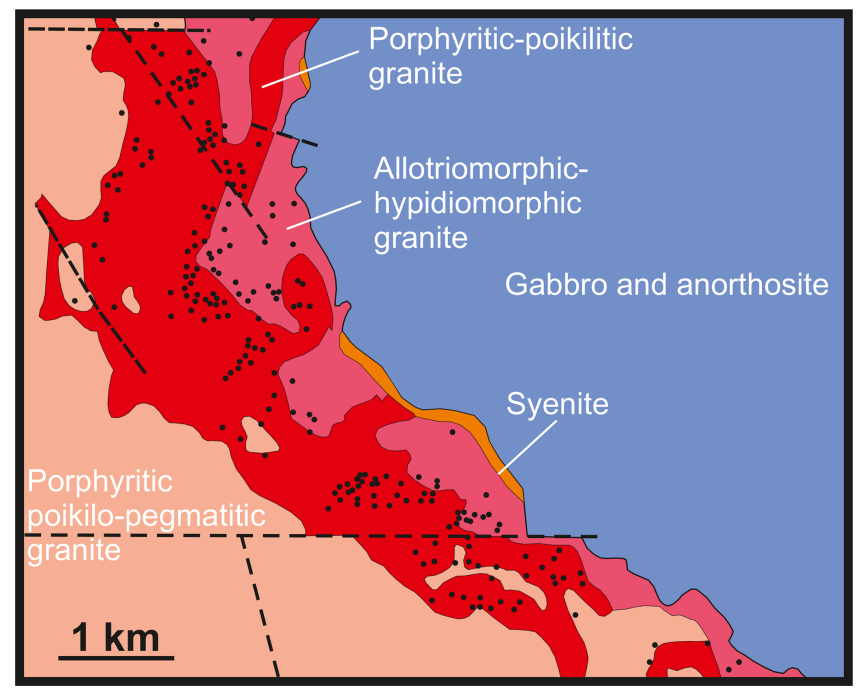

Figure 3. Sketch map of the Volyn pegmatite field simplified based on Lazarenko et al. (1973). Individual pegmatite bodies are indicated by dots.

\section{Samples and analytical methods}

In this study, the results of laser ablation inductively coupled plasma mass spectrometry (LA-ICP-MS) Hf isotope studies from eight zircon samples representing rocks of the KPC are reported (Table 1, Fig. 1). All eight samples were dated using secondary ion mass spectrometry (SIMS): four as part of this study, while the other four were dated previously by Shumlyanskyy et al. (2017). The samples from the earlier study are monzodiorite (sample 71-1M) and syenite (sample 71-9), which occur at the eastern contact of the Volyn gabbro-anorthosite massif with rapakivi granites of the Malyn massif. The other two samples represent rapakivi granites (samples 95005 and 53-7) of the Malyn massif.

Our four new samples represent granites of the western part of the KPC (sample 18K-1: granite from the open pit in Novi Bilokorovychi village; sample 18K-3: granite from the open pit in Sukhovolya village), one pegmatite sample (18K-
2 , from the dump of the underground mine near the city of Khoroshiv), and one sample (18K-2-1) represents the granite host of the pegmatite from the same locality.

For the SIMS analysis, obtained using the CAMECA 1280-HR SIMS instrument at the GFZ Potsdam, the analytical set-up largely follows that of Ashwal et al. (2017) and Glynn et al. (2017). The U-Pb calibration for the analytical session was based on the primary zircon reference material $91500\left({ }^{206} \mathrm{~Pb} /{ }^{238} \mathrm{U}\right.$ age: $1062.4 \pm 0.4 \mathrm{Ma} ;{ }^{207} \mathrm{~Pb} /{ }^{206} \mathrm{~Pb}$ age: $1065.4 \pm 0.3 \mathrm{Ma}$; Wiedenbeck et al., 1995), while Temora $2\left({ }^{206} \mathrm{~Pb} /{ }^{238} \mathrm{U}\right.$ age: $416.78 \pm 0.33 \mathrm{Ma}$; Black et al., 2004) reference material has been used to evaluate the accuracy and stability of the calibration.

Data reduction employed the Excel-based programme "NordAge" (Martin J. Whitehouse, NORDSIM facility, Stockholm), for which 18 measurements made on 91500 were used to establish the $\mathrm{U}-\mathrm{Pb}$ inter-element fractionation against which the unknowns were calibrated using a $\mathrm{Pb} / \mathrm{UO}$ vs. $\mathrm{UO}_{2} / \mathrm{UO}$ relationship employing a power-law fit. This resulted in a mean ${ }^{206} \mathrm{~Pb} /{ }^{238} \mathrm{U}$ age of $1062 \pm 6 \mathrm{Ma}$ (mean squared weighted deviation, MSWD, $=0.39$ ) for 91500 standard. Temora 2, when treated as an unknown, produced a ${ }^{206} \mathrm{~Pb} /{ }^{238} \mathrm{U}$ age of $420 \pm 3 \mathrm{Ma}(\mathrm{MSWD}=0.69$, $N=10$ ). Thus, the reference materials are within the reasonable agreement of their published ${ }^{206} \mathrm{~Pb} /{ }^{238} \mathrm{U}$ ages of 1062.4 and 416.78 Ma respectively, indicating that no gross bias is present in the $\mathrm{U}-\mathrm{Pb}$ determinations.

The Excel programme "Isoplot" (Ludwig, 2012) was used to plot the data using the decay constants recommended by the International Union of Geological Sciences (IUGS) subcommission on geochronology (Steiger and Jäger, 1977), whereas corrections for common lead were based on the observed ${ }^{204} \mathrm{~Pb} /{ }^{206} \mathrm{~Pb}$ ratio in conjunction with the common lead composition from the model of Stacey and Kramers (1975).

The Lu-Hf isotope composition was measured on a $\mathrm{Nu}$ Plasma II multi-collector inductively coupled plasma mass spectrometer at the John de Laeter Centre, Curtin University, Perth, Australia. All isotopes $\left({ }^{180} \mathrm{Hf},{ }^{179} \mathrm{Hf},{ }^{178} \mathrm{Hf}\right.$, 
Table 1. Sample locations and summary of results of age determinations and average $\varepsilon \mathrm{Hf}$ values (for details see Tables 2 and 3 ).

\begin{tabular}{|c|c|c|c|c|c|}
\hline $\begin{array}{l}\text { Sample } \\
\text { number }\end{array}$ & Rock & Location & Coordinates & $\begin{array}{r}\text { U-Pb age, } \\
\mathrm{Ma}\end{array}$ & $\begin{array}{r}\text { Weighted average } \\
\varepsilon \mathrm{Hf} \pm 2 \sigma\end{array}$ \\
\hline $53-7$ & Wiborgite & Myrne village, open pit & $\begin{array}{l}50.64083^{\circ} \mathrm{N}, \\
28.92703^{\circ} \mathrm{E}\end{array}$ & $1763 \pm 6^{*}$ & $-0.8 \pm 1.1$ \\
\hline $71-9$ & Syenite & Buky village, open pit & $\begin{array}{l}50.70953^{\circ} \mathrm{N} \\
28.82945^{\circ} \mathrm{E}\end{array}$ & $1764 \pm 3^{*}$ & $-0.5 \pm 0.7$ \\
\hline 95005 & Granite & Huta-Potiivka village, open pit & $\begin{array}{l}50.70175^{\circ} \mathrm{N}, \\
28.85667^{\circ} \mathrm{E}\end{array}$ & $1765 \pm 3^{*}$ & $-0.4 \pm 1.3$ \\
\hline $71-1 \mathrm{M}$ & Monzodiorite & Buky village, open pit & $\begin{array}{l}50.70953^{\circ} \mathrm{N}, \\
28.82945^{\circ} \mathrm{E}\end{array}$ & $1761 \pm 4^{*}$ & $0.1 \pm 0.7$ \\
\hline $18 \mathrm{~K}-1$ & Granite & Novi Bilokorovychi village, open pit & $\begin{array}{l}51.10388^{\circ} \mathrm{N}, \\
28.08896^{\circ} \mathrm{E}\end{array}$ & $1782 \pm 19$ & $-1.2 \pm 0.5$ \\
\hline $18 \mathrm{~K}-2$ & Pegmatite & City of Khoroshiv, mine dump & $\begin{array}{l}50.60178^{\circ} \mathrm{N}, \\
28.38981^{\circ} \mathrm{E}\end{array}$ & $1760 \pm 3$ & $-1.1 \pm 0.4$ \\
\hline $18 \mathrm{~K}-2-1$ & Granite & City of Khoroshiv & $\begin{array}{l}50.60058^{\circ} \mathrm{N}, \\
28.38717^{\circ} \mathrm{E}\end{array}$ & $1766 \pm 3$ & $-0.5 \pm 0.4$ \\
\hline $18 \mathrm{~K}-3$ & Granite & Sukhovolya village, open pit & $\begin{array}{l}50.67948^{\circ} \mathrm{N}, \\
28.31530^{\circ} \mathrm{E}\end{array}$ & $1771 \pm 9$ & $-0.8 \pm 0.5$ \\
\hline
\end{tabular}

* Ages from Shumlyanskyy et al. (2017)

${ }^{177} \mathrm{Hf},{ }^{176} \mathrm{Hf},{ }^{175} \mathrm{Lu},{ }^{174} \mathrm{Hf},{ }^{173} \mathrm{Yb},{ }^{172} \mathrm{Yb}$, and ${ }^{171} \mathrm{Yb}$ ) were counted on the Faraday collector array. Time-resolved data were baseline subtracted and reduced using the Iolite programme (data reduction scheme based on Woodhead et al., 2004). Contributions of ${ }^{176} \mathrm{Yb}$ and ${ }^{176} \mathrm{Lu}$ were removed from the 176 mass signal using ${ }^{176} \mathrm{Yb} /{ }^{173} \mathrm{Yb}=0.7962$ and ${ }^{176} \mathrm{Lu} /{ }^{175} \mathrm{Lu}=0.02655$ with an exponential-law mass bias correction assuming ${ }^{172} \mathrm{Yb} /{ }^{173} \mathrm{Yb}=1.35274$ (Chu et al., 2002). The interference-corrected ${ }^{176} \mathrm{Hf} /{ }^{177} \mathrm{Hf}$ was normalized to ${ }^{179} \mathrm{Hf} /{ }^{177} \mathrm{Hf}=0.7325$ (Patchett and Tatsumoto, 1980) for mass bias correction. Zircon crystals from the Mud Tank carbonatite were analysed together with the samples in each session to monitor the accuracy of the results. Zircons 91500, Plešovice, GJ-1, and R33 were also run as secondary reference standards. All reference material yielded ${ }^{176} \mathrm{Hf} /{ }^{177} \mathrm{Hf}$ ratios within the uncertainty of their respective reported values. Calculation of initial ${ }^{176} \mathrm{Hf} /{ }^{177} \mathrm{Hf}$ and $\varepsilon$ Hf values for unknown zircons employed the accepted U$\mathrm{Pb}$ age of the sample, a $\lambda^{176} \mathrm{Lu}$ decay constant of $1.867 \times$ $10^{-11}$ (Söderlund et al., 2004), and a present-day chondritic uniform reservoir (CHUR) ${ }^{176} \mathrm{Hf} /{ }^{177} \mathrm{Hf}=0.282785$ and ${ }^{176} \mathrm{Lu} /{ }^{177} \mathrm{Hf}=0.0336$ (Bouvier et al., 2008).

\section{Results}

\subsection{Zircon description}

Zircons from the four samples dated as part of this study all share similar features (Fig. 4). They are subhedral to euhedral and rather large (up to $200-300 \mu \mathrm{m}$ in all samples and up to $500 \mu \mathrm{m}$ in the sample $18 \mathrm{~K}-3$ ) prismatic to prismatic-bipyramidal crystals, hosting numerous mineral inclusions. In many cases, zircons do not reveal zoning and appear mostly homogeneous in backscattered electron (BSE) and cathodoluminescence (CL) images. Oscillatory or simple concentric zoning is relatively rare but prevails in zircons from pegmatite sample $18 \mathrm{~K}-2$. In all four samples, narrow dark alteration rims can be seen in BSE images in some of the crystals. In general, though, all zircons have a typical igneous appearance, being only slightly altered by hydrothermal fluids.

\section{$4.2 \mathrm{U}-\mathrm{Pb}$ geochronology}

Sample 18K-1 (granite from the open pit in Novi Bilokorovychi village) yielded variably discordant results (Table 2 , Fig. 5), with an upper intercept age of $1782 \pm 19 \mathrm{Ma}$ and a lower intercept age of $550 \pm 46 \mathrm{Ma}$. This age is based on 17 individual measurements. Zircons in this sample are characterized by high concentrations of $U$ and Th, which have resulted in partial metamictisation of zircons, a high degree of discordance, and a relatively low accuracy of the age determination. Sample 18K-3 (granite from the open pit in Sukhovolya village) yielded a concordia age of $1771 \pm 9 \mathrm{Ma}$, with all 10 measurements carried out in this sample being concordant. Zircons from this sample have low to moderate $\mathrm{U}$ and $\mathrm{Th}$ concentrations (Table 2). Zircons from granite (sample 18K-2-1, which hosts the pegmatite) sampled at the city of Khoroshiv produced predominantly (10 out of 12 analyses) concordant results yielding a concordia age of $1766 \pm 3 \mathrm{Ma}$. The upper intercept age based on all $12 \mathrm{re}-$ sults is $1760 \pm 7 \mathrm{Ma}$ (Fig. 5). Most of the zircons, except two, analysed in this sample have low to moderate $U$ and Th concentrations. The remaining two crystals revealed high 

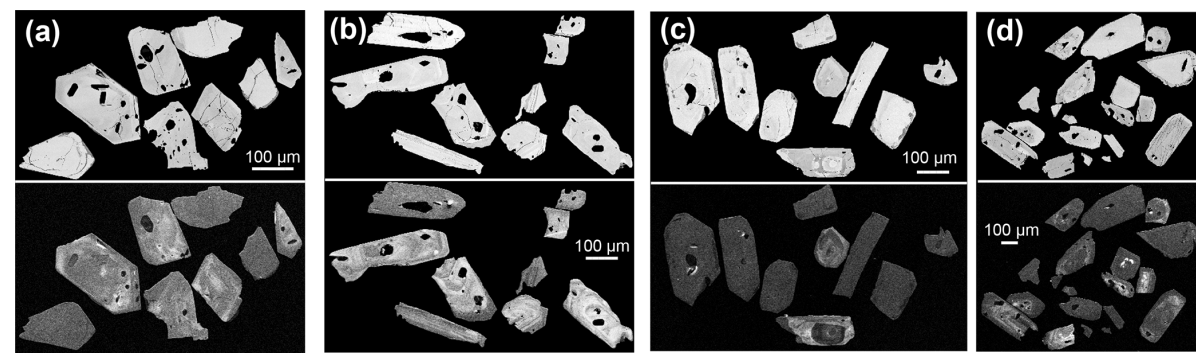

Figure 4. Representative images of zircons extracted from the samples dated as part of this study. Backscattered electron (BSE) images at the top and cathodoluminescence (CL) images at the bottom. (a) Sample 18K-1; (b) sample 18K-2; (c) sample 18K-2-1; (d) sample 18K-3.

concentrations of U (over $2400 \mathrm{ppm}$ ) and yielded heavily discordant ages. Finally, the pegmatite (sample 18K-2) yielded a concordia age of $1760 \pm 3 \mathrm{Ma}$ (based on 8 out of 12 measurements). In general, zircons from pegmatite have the lowest $\mathrm{U}$ and $\mathrm{Pb}$ concentrations among all four studied samples.

A few of the results obtained for granites and pegmatite were heavily discordant with Mesozoic lower intercept ages. No differences between core and rim ages have been detected in any of the samples. Irregular dark areas seen in some zircon grains (see above) all yielded strongly discordant results.

\subsection{Hf isotopes}

Hafnium isotopes were measured in zircons from eight samples, four of which were dated as part of this study, and the other four represent previously dated granites and hybrid rocks. Zircons from these rocks reveal rather wide variations in the initial ${ }^{176} \mathrm{Hf} /{ }^{177} \mathrm{Hf}$ values (Table 3), similar to, or slightly exceeding, those which were previously reported for the rocks of the KPC (Shumlyanskyy et al., 2017). In general, weighted average $\varepsilon \mathrm{Hf}$ values for all eight samples vary between 0.1 and -1.2 . The highest weighted average $\varepsilon \mathrm{Hf}$ value of $0.1 \pm 0.7$ was found in monzogabbro sample $71-1 \mathrm{M}$ that represents the marginal facies of the Volyn massif. Hybrid syenite from the same location revealed an $\varepsilon \mathrm{Hf}$ value of $-0.5 \pm 0.7$. Rapakivi granites have the following weighted average $\varepsilon$ Hf values: sample $95005=-0.4 \pm 1.3$; sample $18 \mathrm{~K}-3=-0.8 \pm 0.5$; sample $53-7=-0.8 \pm 1.1$; sample $18 \mathrm{~K}-2-1=-0.5 \pm 0.4$; and sample $18 \mathrm{~K}-1=-1.2 \pm 0.5$. Finally, zircons from granite pegmatite have a weighted average $\varepsilon \mathrm{Hf}$ value of $-1.1 \pm 0.4$.

\section{Discussion}

\subsection{General magmatic evolution of the Korosten AMCG complex}

The evolution of the KPC, based on the results of the U-Pb dating of various rocks, has been discussed by Shumlyanskyy et al. (2017). Here we provide new data regarding granites, which remain relatively poorly studied in comparison with basic rocks. According to the data, the first pulse of magmatic activity in the KPC took place between 1800 and $1780 \mathrm{Ma}$ when the whole range of magmatic rocks, including anorthosite, gabbro, syenite, jotunite, and granite, crystallized in the northern part of the KPC (Figs. 1, 6). This first pulse started with the emplacement of the early anorthosite series represented by anorthosite and leuconorite-bearing megacrysts of lower-crustal highalumina orthopyroxene (Mitrokhin et al., 2008). These rocks crystallized in the lower crust and occur either as xenoliths in younger rocks or relatively large bodies brought to the surface by tectonic movements. Granites in the northern part of the KPC were formed coevally with the early anorthosite series, as can be seen from relationships with the Davydky gabbro-syenite intrusion, which intruded into granite at $1790 \pm 2 \mathrm{Ma}$ (Shumlyanskyy et al., 2015a). U-Pb zircon ages were determined for three granite samples belonging to this magmatic pulse: $1780 \pm 6 \mathrm{Ma}$ (Bondary open pit; Shumlyanskyy et al., 2017), $1781 \pm 3 \mathrm{Ma}$ (Usove village; Amelin et al., 1994), and $1782 \pm 19 \mathrm{Ma}$ (Bilokorovychi granite; this study). In contrast to the northern part, most of the rocks exposed in the southern half of the KPC crystallized between ca. 1768 and $1755 \mathrm{Ma}$. Large anorthosite bodies of the Volyn massif intruded between ca. 1761 and $1758 \mathrm{Ma}$, while residual melts, represented by pegmatitic pods, crystallized at ca. $1758 \mathrm{Ma}$, indicating that these anorthosite bodies, which are up to $2 \mathrm{~km}$ thick and occupy up to $1000 \mathrm{~km}^{2}$, solidified within a few million years (Shumlyanskyy and Zahnitko, 2011). Numerous gabbroic intrusions in the internal and marginal parts of the anorthosite massifs intruded between 1763 and $1757 \mathrm{Ma}$; their ages are indistinguishable within error from that of the host anorthosite.

Despite the commonly held opinion about the younger age of large granite massifs associated with anorthosite bodies, available geochronological data indicate that this is not the case for the KPC. All rapakivi granites and syenites in the southern half of the KPC have ages within a narrow interval of 1765-1762 Ma. Granites from the city of Khoroshiv $(1766 \pm 3 \mathrm{Ma})$ and Sukhovolya village $(1771 \pm 9 \mathrm{Ma})$ also, within error, fall into this same narrow interval. Small bodies of biotite granite porphyry intruded at ca. $1758 \mathrm{Ma}$, while the youngest rocks of the KPC are subalkaline granites of the Lezniki massif and veins of Li-F microcline-albite granites 
Table 2. U-Pb SIMS results for zircons from granites and pegmatites in the western part of the KPC.

\begin{tabular}{|c|c|c|c|c|c|c|c|c|c|c|c|c|c|c|c|c|c|c|c|c|}
\hline \multirow[b]{2}{*}{ Spot number } & & \multicolumn{9}{|c|}{ Isotope ratios } & \multicolumn{6}{|c|}{ Isotope ages, $\mathrm{Ma}$} & \multicolumn{4}{|c|}{ Concentrations, ppm } \\
\hline & & $\begin{array}{c}{ }^{207} \mathrm{~Pb} \\
{ }^{235} \mathrm{U}\end{array}$ & $\begin{array}{r} \pm \sigma \\
\%\end{array}$ & $\begin{array}{r}{ }^{206} \mathrm{~Pb} \\
{ }^{238} \mathrm{U}\end{array}$ & $\begin{array}{r} \pm \sigma \\
\%\end{array}$ & $r$ & Disc. \% & $\begin{array}{l}{ }^{207} \mathrm{~Pb} \\
{ }^{206} \mathrm{~Pb}\end{array}$ & $\begin{array}{r} \pm \sigma \\
\%\end{array}$ & $\begin{array}{l}{ }^{206} \mathrm{~Pb} \\
{ }^{204} \mathrm{~Pb}\end{array}$ & $\begin{array}{l}{ }^{207} \mathrm{~Pb} \\
{ }^{206} \mathrm{~Pb}\end{array}$ & $\pm \sigma$ & $\begin{array}{c}{ }^{207} \mathrm{~Pb} \\
{ }^{235} \mathrm{U}\end{array}$ & $\pm \sigma$ & $\begin{array}{c}{ }^{206} \mathrm{~Pb} \\
{ }^{238} \mathrm{U}\end{array}$ & $\pm \sigma$ & $\mathrm{U}$ & Th & $\mathrm{Pb}$ & $\mathrm{Th} / \mathrm{U}$ \\
\hline \multicolumn{21}{|c|}{ Sample 18K-1, granite, Novi Bilokorovychi village, $1782 \pm 19 \mathrm{Ma}$} \\
\hline 1 & Core & 4.79825 & 0.90 & 0.3234 & 0.88 & 0.97 & 3.1 & 0.10836 & 0.22 & 18133 & 1759 & 4 & 1785 & 8 & 1806 & 14 & 3012 & 1684 & 1229 & 0.56 \\
\hline 2 & Rim & 0.92340 & 0.97 & 0.0956 & 0.90 & 0.93 & -38.4 & 0.07058 & 0.33 & 27292 & 930 & 7 & 664 & 5 & 589 & 5 & 4957 & 4511 & 628 & 0.91 \\
\hline 3 & Core & 4.72216 & 1.11 & 0.3119 & 0.95 & 0.86 & -3.0 & 0.11025 & 0.55 & 31436 & 1796 & 10 & 1771 & 9 & 1750 & 15 & 265 & 154 & 105 & 0.58 \\
\hline 4 & Rim & 4.71500 & 1.31 & 0.3142 & 1.04 & 0.79 & -1.2 & 0.10885 & 0.81 & 53026 & 1780 & 15 & 1740 & 11 & 1761 & 16 & 223 & 110 & 87 & 0.50 \\
\hline 5 & & 1.42094 & 5.31 & 0.1288 & 5.08 & 0.96 & -36.8 & 0.0803 & 1.55 & 46023 & 1197 & 31 & 898 & 32 & 781 & 37 & 4083 & 2933 & 664 & 0.72 \\
\hline 6 & & 4.85828 & 0.97 & 0.3245 & 0.92 & 0.95 & 2.3 & 0.10876 & 0.28 & 69680 & 1776 & 5 & 1795 & 8 & 1812 & 15 & 1067 & 651 & 443 & 0.61 \\
\hline 7 & Core & 4.92102 & 2.08 & 0.3191 & 1.53 & 0.73 & -2.8 & 0.11186 & 1.41 & 21626 & 1830 & 26 & 1806 & 18 & 1785 & 24 & 137 & 81 & 56 & 0.59 \\
\hline 9 & Rim & 0.82329 & 1.69 & 0.0954 & 1.60 & 0.95 & -16.2 & 0.06321 & 0.51 & 23948 & 695 & 12 & 610 & 8 & 587 & 9 & 4091 & 2007 & 467 & 0.49 \\
\hline 10 & Rim & 1.53907 & 1.69 & 0.1355 & 1.44 & 0.85 & -37.0 & 0.08290 & 0.88 & 28724 & 1255 & 18 & 946 & 11 & 819 & 11 & 3197 & 1595 & 528 & 0.50 \\
\hline 11 & Core & 4.61733 & 0.90 & 0.3101 & 0.85 & 0.95 & -1.6 & 0.10812 & 0.29 & 92377 & 1766 & 5 & 1752 & 8 & 1741 & 13 & 1240 & 595 & 477 & 0.48 \\
\hline 12 & & 3.70957 & 0.94 & 0.2575 & 0.87 & 0.92 & -14.9 & 0.10469 & 0.37 & 61975 & 1705 & 7 & 1573 & 8 & 1477 & 11 & 1431 & 858 & 457 & 0.60 \\
\hline 13 & Core & 4.87984 & 1.31 & 0.3217 & 1.07 & 0.81 & -0.1 & 0.11002 & 0.77 & 81443 & 1800 & 14 & 1799 & 11 & 1798 & 17 & 146 & 61 & 58 & 0.42 \\
\hline 14 & Rim & 4.59424 & 1.18 & 0.3103 & 0.91 & 0.77 & -0.9 & 0.11646 & 0.46 & 1501 & 1756 & 14 & 1748 & 10 & 1742 & 14 & 375 & 177 & 143 & 0.47 \\
\hline 15 & & 3.59898 & 2.21 & 0.2532 & 2.17 & 0.98 & -15.0 & 0.10328 & 0.44 & 69578 & 1680 & 8 & 1549 & 18 & 1455 & 28 & 3588 & 1061 & 1077 & 0.30 \\
\hline 16 & & 4.84814 & 0.94 & 0.3241 & 0.87 & 0.92 & 2.3 & 0.10849 & 0.37 & 184445 & 1774 & 7 & 1793 & 8 & 1810 & 14 & 670 & 423 & 280 & 0.63 \\
\hline 17 & & 1.03436 & 3.19 & 0.1108 & 3.04 & 0.95 & -22.2 & 0.06836 & 0.95 & 21316 & 859 & 21 & 721 & 17 & 678 & 20 & 3976 & 1134 & 507 & 0.29 \\
\hline \multicolumn{21}{|c|}{ Sample $18 \mathrm{~K}-2$, pegmatite, city of Khoroshiv, $1760 \pm 3 \mathrm{Ma}$} \\
\hline 1 & Core & 4.68159 & 0.99 & 0.3147 & 0.92 & 0.93 & 0.0 & 0.10788 & 0.36 & 281774 & 1764 & 7 & 1764 & 8 & 1764 & 14 & 534 & 241 & 210 & 0.45 \\
\hline 2 & Core & 4.71002 & 0.94 & 0.3162 & 0.88 & 0.94 & 0.3 & 0.10814 & 0.33 & 128340 & 1767 & 6 & 1769 & 8 & 1771 & 14 & 603 & 351 & 244 & 0.58 \\
\hline 3 & & 1.18922 & 3.02 & 0.0957 & 2.44 & 0.81 & -61.4 & 0.12487 & 0.96 & 401 & 1428 & 34 & 796 & 17 & 589 & 14 & 1016 & 498 & 125 & 0.49 \\
\hline 4 & & 3.02056 & 1.28 & 0.2069 & 1.15 & 0.90 & -32.8 & 0.10743 & 0.50 & 8856 & 1730 & 10 & 1413 & 10 & 1212 & 13 & 340 & 124 & 87 & 0.36 \\
\hline 5 & Core & 2.59643 & 3.76 & 0.1757 & 1.22 & 0.33 & -43.7 & 0.15226 & 1.54 & 302 & 1752 & 65 & 1300 & 28 & 1044 & 12 & 207 & 355 & 49 & 1.72 \\
\hline 6 & Core & 4.61852 & 1.49 & 0.3137 & 1.13 & 0.76 & 0.9 & 0.10679 & 0.97 & 16253 & 1745 & 18 & 1753 & 13 & 1759 & 17 & 73 & 38 & 29 & 0.52 \\
\hline 7 & Rim & 4.65163 & 1.25 & 0.3143 & 1.04 & 0.83 & 0.5 & 0.10734 & 0.69 & 73756 & 1755 & 13 & 1759 & 11 & 1762 & 16 & 142 & 64 & 55 & 0.45 \\
\hline 8 & & 4.69080 & 1.26 & 0.3148 & 1.00 & 0.80 & -0.2 & 0.10808 & 0.76 & 84634 & 1767 & 14 & 1766 & 11 & 1764 & 16 & 217 & 103 & 85 & 0.48 \\
\hline 9 & Rim & 4.55507 & 1.04 & 0.3061 & 0.95 & 0.91 & -2.8 & 0.10840 & & 29064 & 1765 & 8 & 1741 & 9 & 1721 & 14 & 368 & 140 & 137 & 0.38 \\
\hline 10 & Core & 4.65125 & 1.43 & 0.3116 & 1.19 & 0. & -1.4 & 0.10827 & & 56647 & 1771 & 14 & & 12 & & 8 & 110 & 61 & 43 & 0.56 \\
\hline 11 & & 2.66010 & 1.36 & 0.2 & 0.93 & 0.68 & -21.6 & 0.1 & 0.47 & 937 & 1503 & 19 & 1 & 10 & 1207 & 10 & 476 & 371 & 127 & 0.78 \\
\hline 12 & & 4.64035 & 1.10 & 0.3138 & 1.01 & 0.92 & 0.4 & 0.10775 & 0.40 & 27657 & 1753 & 8 & 1757 & 9 & 1759 & 16 & 365 & 229 & 148 & 0.63 \\
\hline \multicolumn{21}{|c|}{ Sample 18K-2-1, granite, city of Khoroshiv, $1766 \pm 3 \mathrm{Ma}$} \\
\hline 1 & & 4.67760 & 1.01 & 101 & 0.93 & 0.92 & 1.5 & 713 & 0.40 & 208874 & 1751 & 7 & 1763 & 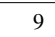 & 1774 & 14 & 357 & 229 & 147 & 0.64 \\
\hline 2 & & 4.70847 & 1.62 & 0.3146 & 1.49 & 0.92 & -0.8 & 0.10856 & 0.64 & 308409 & 1775 & 12 & 1769 & 14 & 1763 & 23 & 518 & 240 & 202 & 0.46 \\
\hline 3 & & 0.22591 & 2.91 & 0.0204 & 1.09 & 0.37 & -90 & 0.12177 & 0.55 & 340 & 1203 & 53 & 207 & 6 & 130 & 2 & 3805 & 1059 & 92 & 0.28 \\
\hline 4 & & 4.68851 & 1.01 & 0.3152 & 0.89 & 0.88 & 0.2 & 0. & 0.47 & 704371 & 1764 & 9 & 1765 & 9 & 1767 & 14 & 533 & 302 & 214 & 0.57 \\
\hline 5 & Rim & 4.39849 & 1.29 & 0.2975 & 1.03 & 0.80 & -4.8 & 0.10724 & 0.78 & $>1 \mathrm{e} 6$ & 1753 & 14 & 1712 & 11 & 16 & 15 & 120 & 64 & 45 & 0.54 \\
\hline 6 & Rim & 4.74712 & 0.94 & 0.3190 & 0.89 & 0.95 & 1.3 & 0.10792 & 0.31 & 338542 & 1765 & 6 & 1776 & 8 & 1785 & 14 & 1062 & 891 & 458 & 0.84 \\
\hline 7 & Core & 4.75944 & 1.00 & 0.3214 & 0.96 & 0.97 & 2.6 & 0.10741 & 0.26 & 396078 & 1756 & 5 & 1778 & 8 & 1796 & 15 & 997 & 973 & 446 & 0.98 \\
\hline 8 & Core & 4.67579 & 0.95 & 0.3147 & 0.88 & 0.92 & 0.2 & 0.10774 & 0.36 & 133216 & 1762 & 7 & 1763 & 8 & 1764 & 14 & 515 & 210 & 199 & 0.41 \\
\hline 9 & & 4.67798 & 1.00 & 0.3144 & 0.87 & 0.87 & -0.2 & 0.10792 & 0.50 & 172999 & 1765 & 9 & 1763 & 8 & 1762 & 13 & 652 & 198 & 245 & 0.30 \\
\hline 10 & & 4.73871 & 1.01 & 0.3189 & 0.96 & 0.96 & 1.5 & 0.10776 & 0.29 & 526234 & 1762 & 5 & 1774 & 9 & 1785 & 15 & 762 & 500 & 316 & 0.66 \\
\hline 11 & & 0.33812 & 2.58 & 0.0323 & 1.68 & 0.65 & -82.6 & 0.11559 & 0.59 & 359 & 1095 & 39 & 296 & 7 & 205 & 3 & 2435 & 477 & 87 & 0.20 \\
\hline 12 & & 4.72266 & 1.17 & 0.3193 & 1.08 & 0.92 & 2.2 & 0.10726 & 0.45 & 472908 & 1753 & 8 & 1771 & 10 & 1787 & 17 & 436 & 309 & 182 & 0.71 \\
\hline \multicolumn{21}{|c|}{ Sample 18K-3, granite, Sukhovolya village, $1771 \pm 9 \mathrm{Ma}$} \\
\hline 1 & Core & 4.77760 & 1.16 & 0.3193 & 0.93 & 0.80 & & 0.10850 & 0.69 & 63513 & 1775 & 13 & 1781 & 10 & 1787 & 15 & 399 & 269 & 166 & 0.67 \\
\hline 2 & Core & 4.77437 & 0.99 & 0.3199 & 0.92 & 0.93 & 1.2 & 0.10825 & 0.35 & 191588 & 1770 & 7 & 1780 & 8 & 1789 & 14 & 917 & 320 & 354 & 0.35 \\
\hline 3 & & 4.70779 & 1.29 & 0.3213 & 1.00 & 0.78 & 3.9 & 0.10628 & 0.81 & 64043 & 1737 & 15 & 1769 & 11 & 1796 & 16 & 160 & 92 & 65 & 0.58 \\
\hline 4 & & 4.74341 & 1.03 & 0.3198 & 0.94 & 0.92 & 2.0 & 0.10757 & 0.41 & 156740 & 1759 & 7 & 1775 & 9 & 1789 & 15 & 502 & 263 & 202 & 0.52 \\
\hline 5 & Core & 4.76907 & 1.36 & 0.3230 & 1.27 & 0.94 & 3.6 & 0.10707 & 0.47 & 79018 & 1750 & 9 & 1780 & 12 & 1805 & 20 & 377 & 275 & 160 & 0.73 \\
\hline 6 & Core & 4.73208 & 0.97 & 0.3192 & 0.90 & 0.93 & 1.8 & 0.10754 & 0.35 & 105749 & 1758 & 7 & 1773 & 8 & 1786 & 14 & 763 & 355 & 301 & 0.47 \\
\hline 7 & Core & 4.70542 & 1.34 & 0.3157 & 1.07 & 0.80 & 0.1 & 0.10808 & 0.79 & 214581 & 1767 & 15 & 1768 & 11 & 1769 & 14 & 226 & 177 & 95 & 0.78 \\
\hline 8 & & 4.66249 & 3.79 & 0.3057 & 2.89 & 0.76 & -5.7 & 0.11061 & 2.45 & 215893 & 1810 & 45 & 1761 & 32 & 1720 & 44 & 1027 & 437 & 382 & 0.43 \\
\hline 9 & & 4.70428 & 2.15 & 0.3101 & 1.43 & 0.67 & -3.7 & 0.11002 & 1.60 & 8662 & 1800 & 29 & 1768 & 18 & 1741 & 22 & 91 & 52 & 36 & 0.57 \\
\hline 10 & Core & 4.79560 & 1.38 & 0.3184 & 1.09 & 0.79 & -0.3 & 0.10922 & 0.84 & 37202 & 1787 & 15 & 1784 & 12 & 1782 & 17 & 189 & 91 & 74 & 0.48 \\
\hline
\end{tabular}

$(1752 \pm 8$ and $1742 \pm 9 \mathrm{Ma}$, respectively; Shumlyanskyy et al., 2017).

Hence, during the first phase of magmatic activity basic and felsic rocks crystallized coevally. During this stage, anorthosites crystallized mainly in the lower crust, whereas felsic melts intruded into the upper crust. Upper-crustal mafic rocks of this phase are gabbro-syenites of the Davydky intrusion and several jotunite dykes. The second phase of magmatic activity started with emplacement of the large rapakivi granite massifs, followed soon by several large gabbroanorthosite intrusions into the upper crust.

Hafnium isotope compositions in zircons from different rocks do not reveal systematic variations with age (Fig. 7). All rocks, irrespective of their composition (except sample 06-BG47: the late jotunite sill from the Bondary open pit), have near-chondritic $\mathrm{Hf}$ isotope values between +3 and -3 . On average, zircons from gabbros and anorthosites reveal slightly higher $\varepsilon \mathrm{Hf}$ values than felsic rocks, but considering 


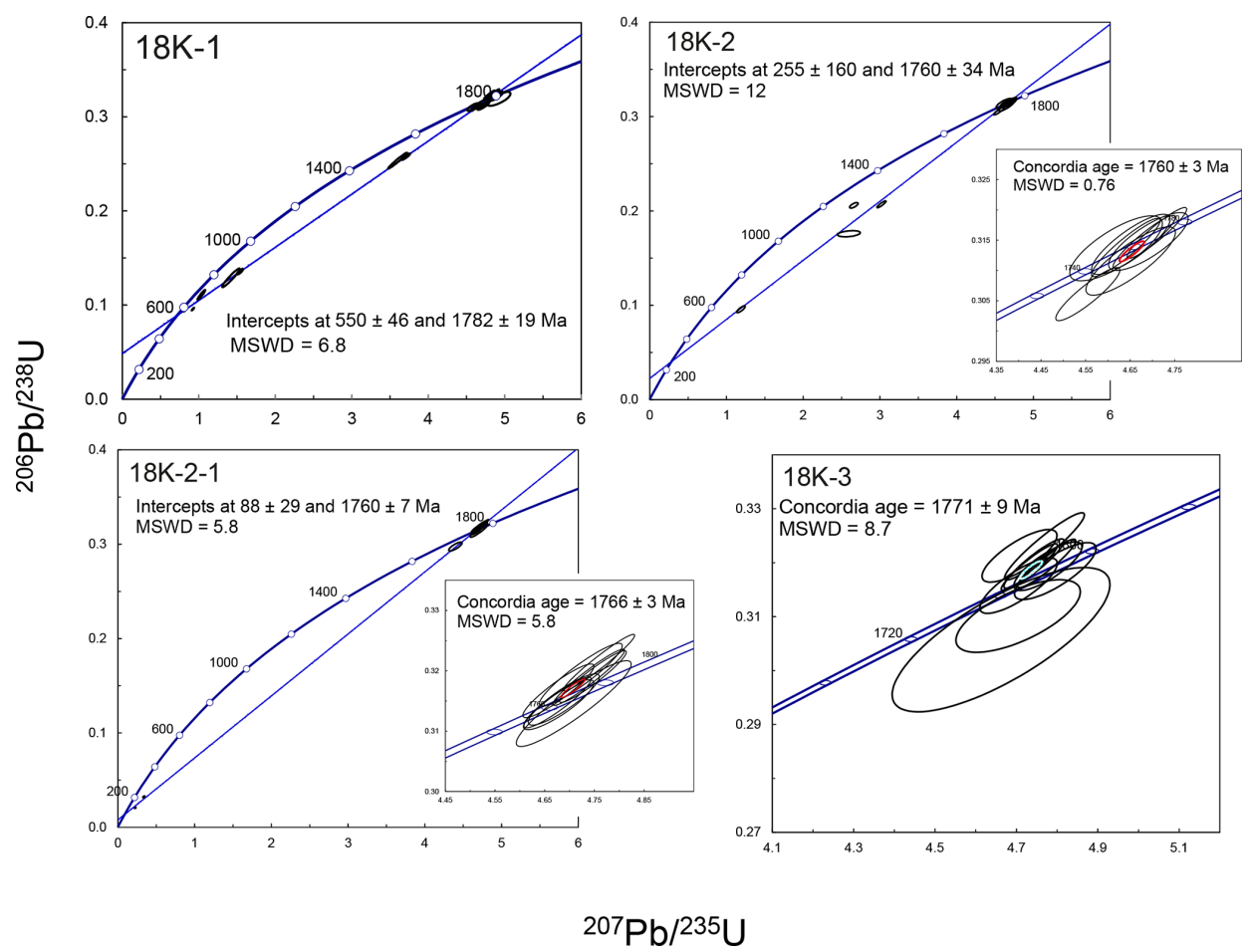

Figure 5. U-Pb concordia diagrams for granites and pegmatite in the western part of the Korosten plutonic complex. Uncertainty on the ellipses in the concordia age plots is at the 1 standard deviation level.

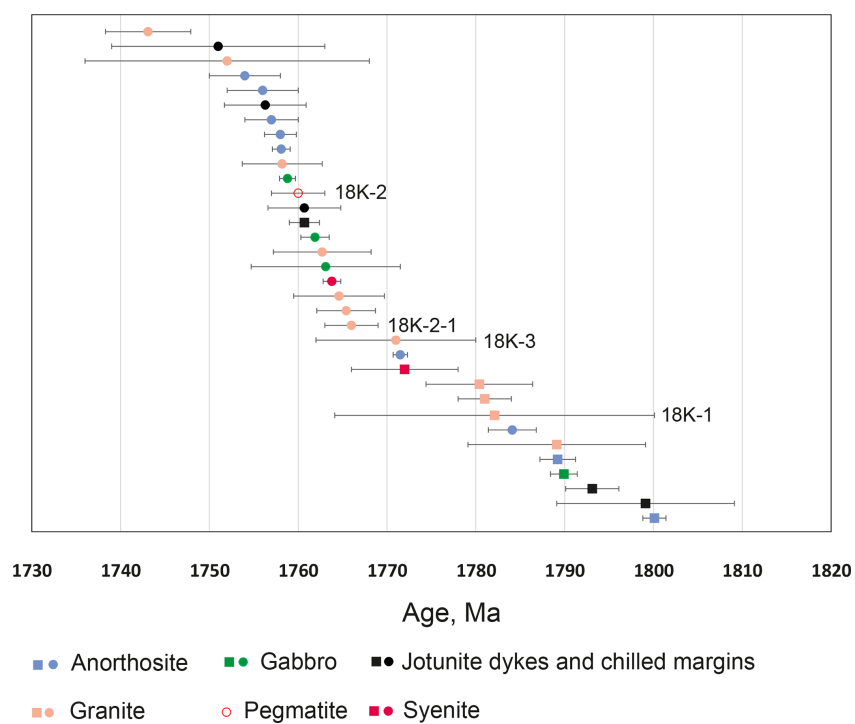

Figure 6. An overview of the temporal evolution of magmatism in the Korosten plutonic complex. Newly obtained ages are indicated by sample numbers. Squares indicate samples collected in the northern part of the complex, while circles show samples collected in the southern part of the complex.

significant within-sample variations (Table 3), isotope compositions of different lithologies overlap. Hence, our new $\mathrm{Hf}$ isotope data agree with the previous conclusions proposed by
Shumlyanskyy et al. $(2006,2017)$ regarding a predominantly crustal source for the parental magma, with some input of juvenile material from coeval mantle-derived tholeiite melts.

\subsection{Origin and evolution of chamber pegmatites}

According to Voznyak and Pavlyshyn (2008), chamber pegmatites of the Volyn pegmatite field crystallized at a relatively shallow depth of less than $3.5 \mathrm{~km}$. As the level of erosion throughout the KPC does not exceed the first few kilometres, chamber pegmatites can potentially be found everywhere in the complex, and indeed, miarolitic cavities up to a dozen centimetres in size are common in granites of the KPC and are found in multiple different places (Lazarenko et al., 1973). However, large chamber pegmatites, reaching hundreds of cubic metres in volume (e.g. Lyckberg et al., 2019), occur only in the Volyn pegmatite field.

Pegmatite chambers are formed when the host granite remains in a semi-crystallized, plastic state, thus allowing the fluid to overcome the lithostatic pressure and inflate the chamber. At a later stage, the semi-crystallized granite forms an interlocking crystal network thereby losing its ability to form cavities. As a result, the time interval during which pegmatite chambers can be formed is relatively short. So, there must be some additional factor acting specifically in the Volyn pegmatite field which is extending the common miarole-forming process allowing for the formation of large chamber pegmatites. 


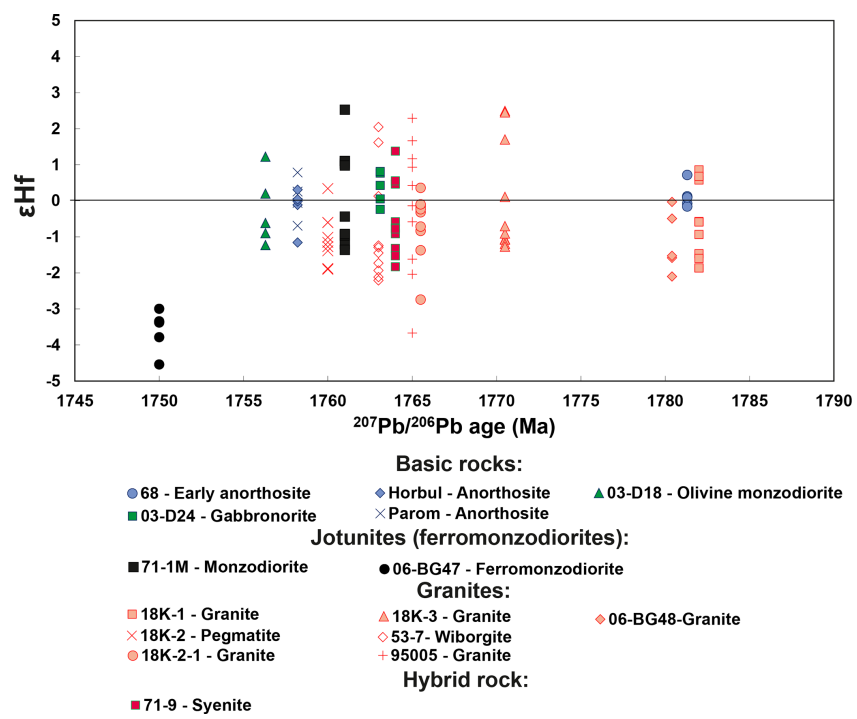

Figure 7. Hafnium isotope evolution diagram for zircons from rocks of the KPC. Data from Shumlyanskyy et al. (2017) and this study.

Volatiles dissolved in rising crystallizing magmatic melts can exsolve when they reach the solubility limit due to cooling, decompression, or magma crystallization. As melts rise in the crust, they gradually become saturated with respect to the dissolved volatiles and at the new $P-T$ conditions expel volatiles as a fluid phase (e.g. Baker and Alletti, 2012; Shishkina et al., 2014). The first exsolving phase is $\mathrm{CO}_{2}$ rich gas, followed by $\mathrm{H}_{2} \mathrm{O}$ - and S-rich fluids (Capriolo et al., 2020). At the final stages of crystallization, the volatiles concentrate in the residual melt and finally exsolve forming a gaseous phase and hydrous fluids, commonly brines with a high concentration of salts, depending on the chemical composition of the magma (Sisson and Bacon, 1999; Masotta et al., 2010; Blundy et al., 2015; Afanasyev et al., 2018). For the Volyn pegmatite field the magma must have been rich in $F$ because the pegmatites are characterized by a large amount of topaz, which would decrease the lowest melt temperature significantly. However, for a detailed evaluation of the type of evolving fluids, the necessary geochemical data (e.g. concentration of $\mathrm{F}, \mathrm{Cl}, \mathrm{S}$ ) for the magmas are missing. Exsolution of gases and hydrous fluids is a very common process that accompanies the evolution of any magmatic system. It results in various specific textures, including miarolitic cavities, that can be seen in felsic intrusions (Vigneresse, 2015). However, the formation of huge pegmatite chambers requires special conditions, which can occur (a) when the process of granitic melt crystallization is extended, i.e. when the miarole-forming $P-T$ conditions are maintained for a prolonged time, and (b) when a continuous flow of gases and hydrous fluids is maintained.

Geological data indicate that emplacement of basic rocks of the Volyn gabbro-anorthosite massif took place when the host granite was still not fully solidified, allowing for the mingling and hybridization of two melts (Mitrokhin and Bilan, 2014; see also Fig. 2). According to geophysical data (e.g. Lichak, 1983; Bogdanova et al., 2004), basic rocks not only border and partly overlay granites in the south-western part of the KPC, but they also underlay them. Geochronological data demonstrate now that granites were emplaced a few million years earlier than the basic rocks of the Volyn gabbro-anorthosite massif, whereas the age of pegmatites coincides with the emplacement of basic rocks (Fig. 6). This means that during the whole period of cooling of the large amounts of anorthositic-gabbroic melts, the granitepegmatite system remained at a high temperature, allowing for the effective concentration of all exsolving fluids into specific areas.

Previous researchers (Ivantyshyn et al., 1957; Marakushev et al., 1989) pointed out the presence of Fe-hedenbergite and fayalite, as well as enrichment in $\mathrm{TiO}_{2}$ and $\mathrm{FeO}_{\text {tot }}$ in granites near contacts with the anorthosite massifs, which can be explained by "hybridization" of granites under the influence of intruding basic magmas. An even more pronounced impact of the basic melts on granites which was noticed in zones of mafic mineral enrichment is that they contain more calcic plagioclase than the surrounding granite (Marakushev et al., 1989). Considering all these lines of evidence, we assume that the emplacement of basic melts and their subsequent interaction with the partly solidified granites played a crucial role in the formation of the chamber pegmatites: the degassing of basic magmas at shallow levels resulted in the infiltration of additional fluids and gases into the overlying partly crystallized granite massif, ultimately resulting in the formation of the chamber pegmatites. Vozniak and Pavlyshyn (2008) and Vozniak et al. (2012) were the first to demonstrate the role of gases and fluids derived from the basic melts on the formation of the chamber pegmatites in the Volyn pegmatite field. Studying fluid inclusions in quartz, topaz, and beryl, they have recorded a temperature increase during the late stages of crystallization and an input of sufficient amounts of $\mathrm{CO}_{2}$, which probably corresponds to the emplacement of basic melts.

Our model for the formation of chamber pegmatites in the Volyn pegmatite field includes several stages. The first stage corresponds to the formation of rather small "incipient" chambers (i.e. the miarolitic cavities) that are developed due to degassing of the granitic melts at shallow levels. The second stage follows when the basic melts intrude the partly crystallized granite massif, resulting in a hybridization of the melts. Lastly, reheating of the granites and degassing of the basic melts allows the exsolved fluids and gases to infiltrate the chambers in the granite massif forming the pegmatites. All of these processes together facilitate the inflation of giant cavities that are then subsequently filled with residual silicic melts, mineralizing fluids, and gases.

Considering the mineral assemblages that develop in the pegmatite bodies, at least one magmatic and several hy- 
Table 3. Hafnium isotope compositions in zircons from the studied rocks of the Korosten plutonic complex.

\begin{tabular}{|c|c|c|c|c|c|c|c|}
\hline No. & ${ }^{176} \mathrm{Lu} /{ }^{177} \mathrm{Hf}$ & ${ }^{176} \mathrm{Yb} /{ }^{177} \mathrm{Hf}$ & ${ }^{176} \mathrm{Hf} /{ }^{177} \mathrm{Hf}$ & $\pm 1 \sigma$ & ${ }^{176} \mathrm{Hf} /{ }^{177} \mathrm{Hf}_{T}$ & $\varepsilon \mathrm{Hf}_{T}$ & $\pm 2 \sigma$ \\
\hline \multicolumn{8}{|c|}{ Sample 53-7, wiborgite, Myrne village, $1763 \pm 6 \mathrm{Ma}$} \\
\hline 1 & 0.000574 & 0.015900 & 0.281645 & 0.000034 & 0.281626 & -1.2 & 2.4 \\
\hline 2 & 0.000767 & 0.021500 & 0.281650 & 0.000033 & 0.281624 & -1.3 & 2.3 \\
\hline 3 & 0.000720 & 0.019510 & 0.281636 & 0.000034 & 0.281612 & -1.7 & 2.4 \\
\hline 4 & 0.000673 & 0.018200 & 0.281621 & 0.000039 & 0.281598 & -2.2 & 2.7 \\
\hline 5 & 0.000950 & 0.025500 & 0.281738 & 0.000036 & 0.281706 & 1.6 & 2.6 \\
\hline 6 & 0.000656 & 0.017690 & 0.281623 & 0.000037 & 0.281601 & -2.1 & 2.6 \\
\hline 7 & 0.000975 & 0.026100 & 0.281751 & 0.000035 & 0.281718 & 2.0 & 2.5 \\
\hline 8 & 0.000539 & 0.014310 & 0.281638 & 0.000035 & 0.281620 & -1.4 & 2.5 \\
\hline 9 & 0.000500 & 0.013250 & 0.281623 & 0.000034 & 0.281606 & -1.9 & 2.4 \\
\hline 10 & 0.000798 & 0.021960 & 0.281691 & 0.000036 & 0.281664 & 0.1 & 2.6 \\
\hline \multicolumn{8}{|c|}{ Sample 71-9, syenite, Buky village, $1764 \pm 3 \mathrm{Ma}$} \\
\hline 1 & 0.003140 & 0.090100 & 0.281804 & 0.000044 & 0.281699 & 1.4 & 3.1 \\
\hline 2 & 0.000755 & 0.020500 & 0.281669 & 0.000034 & 0.281644 & -0.6 & 2.4 \\
\hline 3 & 0.001390 & 0.039500 & 0.281655 & 0.000035 & 0.281608 & -1.8 & 2.5 \\
\hline 4 & 0.001283 & 0.036010 & 0.281716 & 0.000032 & 0.281673 & 0.5 & 2.2 \\
\hline 5 & 0.000967 & 0.026500 & 0.281708 & 0.000029 & 0.281676 & 0.6 & 2.0 \\
\hline 6 & 0.001187 & 0.033380 & 0.281674 & 0.000040 & 0.281634 & -0.9 & 2.8 \\
\hline 7 & 0.001530 & 0.041400 & 0.281690 & 0.000029 & 0.281639 & -0.8 & 2.0 \\
\hline 8 & 0.001729 & 0.049980 & 0.281696 & 0.000036 & 0.281638 & -0.8 & 2.5 \\
\hline 9 & 0.001020 & 0.027800 & 0.281657 & 0.000039 & 0.281623 & -1.3 & 2.7 \\
\hline 10 & 0.000687 & 0.018220 & 0.281640 & 0.000032 & 0.281617 & -1.5 & 2.3 \\
\hline \multicolumn{8}{|c|}{ Sample 95005, granite, Huta-Potiivka village, $1765 \pm 3 \mathrm{Ma}$} \\
\hline 1 & 0.002410 & 0.069500 & 0.281773 & 0.000047 & 0.281692 & 1.2 & 3.4 \\
\hline 2 & 0.001900 & 0.055000 & 0.281735 & 0.000038 & 0.281671 & 0.4 & 2.7 \\
\hline 3 & 0.002190 & 0.062500 & 0.281759 & 0.000033 & 0.281686 & 0.9 & 2.3 \\
\hline 4 & 0.002540 & 0.071200 & 0.281728 & 0.000037 & 0.281643 & -0.6 & 2.6 \\
\hline 5 & 0.001230 & 0.034900 & 0.281655 & 0.000033 & 0.281614 & -1.6 & 2.4 \\
\hline 6 & 0.002779 & 0.077800 & 0.281817 & 0.000037 & 0.281724 & 2.3 & 2.6 \\
\hline 7 & 0.001310 & 0.037100 & 0.281600 & 0.000035 & 0.281556 & -3.7 & 2.5 \\
\hline 8 & 0.001507 & 0.041800 & 0.281706 & 0.000041 & 0.281655 & -0.1 & 2.9 \\
\hline 9 & 0.002180 & 0.066200 & 0.281675 & 0.000028 & 0.281602 & -2.0 & 2.0 \\
\hline 10 & 0.002737 & 0.078600 & 0.281798 & 0.000039 & 0.281706 & 1.7 & 2.8 \\
\hline \multicolumn{8}{|c|}{ Sample $71-1 \mathrm{M}$, monzodiorite, Buky village, $1761 \pm 4 \mathrm{Ma}$} \\
\hline 1 & 0.000568 & 0.015140 & 0.281647 & 0.000032 & 0.281628 & -1.2 & 2.3 \\
\hline 2 & 0.001028 & 0.028190 & 0.281684 & 0.000037 & 0.281650 & -0.4 & 2.6 \\
\hline 3 & 0.000687 & 0.018750 & 0.281658 & 0.000032 & 0.281635 & -1.0 & 2.3 \\
\hline 4 & 0.000506 & 0.013570 & 0.281653 & 0.000033 & 0.281636 & -0.9 & 2.3 \\
\hline 5 & 0.002566 & 0.072700 & 0.281819 & 0.000042 & 0.281733 & 2.5 & 3.0 \\
\hline 6 & 0.000562 & 0.015250 & 0.281712 & 0.000034 & 0.281693 & 1.1 & 2.4 \\
\hline 7 & 0.000804 & 0.022070 & 0.281718 & 0.000033 & 0.281691 & 1.0 & 2.3 \\
\hline 8 & 0.000984 & 0.027090 & 0.281726 & 0.000032 & 0.281693 & 1.1 & 2.2 \\
\hline 9 & 0.000608 & 0.016400 & 0.281644 & 0.000030 & 0.281624 & -1.4 & 2.1 \\
\hline 10 & 0.000491 & 0.013060 & 0.281706 & 0.000032 & 0.281690 & 1.0 & 2.3 \\
\hline
\end{tabular}

drothermal assemblages can be distinguished (Lazarenko et al., 1973). The magmatic assemblage includes minerals that form the outer parts of the pegmatite bodies, first of all eutectic intergrowths of quartz and feldspars (so-called "graphic granite"). Our zircons were separated from this part of the pegmatite, and their age thus corresponds to the early stages of the pegmatite formation. In contrast, internal portions of the pegmatite bodies are composed of giant crystals of various minerals, which, according to the results of fluid inclusion studies (e.g. Lazarenko et al., 1973; Vozniak and 
Table 3. Continued.

\begin{tabular}{|c|c|c|c|c|c|c|c|}
\hline No. & ${ }^{176} \mathrm{Lu} /{ }^{177} \mathrm{Hf}$ & ${ }^{176} \mathrm{Yb} /{ }^{177} \mathrm{Hf}$ & ${ }^{176} \mathrm{Hf} /{ }^{177} \mathrm{Hf}$ & $\pm 1 \sigma$ & ${ }^{176} \mathrm{Hf} /{ }^{177} \mathrm{Hf}_{T}$ & $\varepsilon \mathrm{Hf}_{T}$ & $\pm 2 \sigma$ \\
\hline \multicolumn{8}{|c|}{ Sample $18 \mathrm{~K}-1$, granite, Novi Bilokorovychi village, $1782 \pm 18 \mathrm{Ma}$} \\
\hline 1 & 0.000796 & 0.031100 & 0.281634 & 0.000017 & 0.281607 & -1.5 & 1.2 \\
\hline 2 & 0.003307 & 0.140300 & 0.281744 & 0.000022 & 0.281632 & -0.6 & 1.6 \\
\hline 3 & 0.000429 & 0.015590 & 0.281687 & 0.000039 & 0.281672 & 0.9 & 2.7 \\
\hline 4 & 0.000535 & 0.021010 & 0.281614 & 0.000018 & 0.281596 & -1.9 & 1.3 \\
\hline 5 & 0.001005 & 0.042500 & 0.281656 & 0.000029 & 0.281622 & -0.9 & 2.0 \\
\hline 6 & 0.002770 & 0.122200 & 0.281697 & 0.000016 & 0.281603 & -1.6 & 1.1 \\
\hline 7 & 0.004857 & 0.203100 & 0.281829 & 0.000032 & 0.281665 & 0.6 & 2.2 \\
\hline 8 & 0.001671 & 0.072000 & 0.281724 & 0.000090 & 0.281667 & 0.7 & 6.4 \\
\hline 9 & 0.000953 & 0.037920 & 0.281664 & 0.000021 & 0.281632 & -0.6 & 1.5 \\
\hline 10 & 0.001008 & 0.040460 & 0.281630 & 0.000016 & 0.281596 & -1.9 & 1.1 \\
\hline \multicolumn{8}{|c|}{ Sample $18 \mathrm{~K}-2$, pegmatite, city of Khoroshiv, $1760 \pm 3 \mathrm{Ma}$} \\
\hline 1 & 0.000745 & 0.030300 & 0.281655 & 0.000015 & 0.281630 & -1.2 & 1.1 \\
\hline 2 & 0.001354 & 0.055300 & 0.281672 & 0.000019 & 0.281627 & -1.3 & 1.3 \\
\hline 3 & 0.001000 & 0.040000 & 0.281679 & 0.000016 & 0.281646 & -0.6 & 1.1 \\
\hline 4 & 0.000506 & 0.023500 & 0.281626 & 0.000015 & 0.281609 & -1.9 & 1.1 \\
\hline 5 & 0.002110 & 0.091600 & 0.281694 & 0.000065 & 0.281623 & -1.4 & 4.6 \\
\hline 6 & 0.000925 & 0.037800 & 0.281665 & 0.000022 & 0.281634 & -1.0 & 1.6 \\
\hline 7 & 0.000472 & 0.017900 & 0.281688 & 0.000023 & 0.281672 & 0.3 & 1.6 \\
\hline 8 & 0.001713 & 0.080500 & 0.281667 & 0.000022 & 0.281610 & -1.9 & 1.5 \\
\hline 9 & 0.001172 & 0.040500 & 0.281875 & 0.000023 & 0.281836 & 6.2 & 1.6 \\
\hline 10 & 0.000486 & 0.018690 & 0.281662 & 0.000019 & 0.281646 & -0.6 & 1.3 \\
\hline \multicolumn{8}{|c|}{ Sample $18 \mathrm{~K}-2-1$, granite, city of Khoroshiv, $1766 \pm 3 \mathrm{Ma}$} \\
\hline 1 & 0.000938 & 0.037600 & 0.281667 & 0.000019 & 0.281636 & -0.8 & 1.3 \\
\hline 2 & 0.001850 & 0.077600 & 0.281718 & 0.000026 & 0.281656 & -0.1 & 1.8 \\
\hline 3 & 0.000911 & 0.037200 & 0.281685 & 0.000019 & 0.281654 & -0.2 & 1.4 \\
\hline 4 & 0.001080 & 0.046500 & 0.281618 & 0.000018 & 0.281582 & -2.7 & 1.3 \\
\hline 5 & 0.001697 & 0.071200 & 0.281707 & 0.000023 & 0.281650 & -0.3 & 1.6 \\
\hline 6 & 0.000702 & 0.029240 & 0.281676 & 0.000019 & 0.281652 & -0.2 & 1.3 \\
\hline 7 & 0.001150 & 0.046400 & 0.281659 & 0.000013 & 0.281620 & -1.4 & 0.9 \\
\hline 8 & 0.001048 & 0.043000 & 0.281674 & 0.000022 & 0.281639 & -0.7 & 1.5 \\
\hline 9 & 0.001130 & 0.046700 & 0.281707 & 0.000018 & 0.281669 & 0.4 & 1.2 \\
\hline 10 & 0.000887 & 0.036200 & 0.281686 & 0.000020 & 0.281656 & -0.1 & 1.4 \\
\hline \multicolumn{8}{|c|}{ Sample $18 \mathrm{~K}-3$, granite, Sukhovolya village, $1771 \pm 9 \mathrm{Ma}$} \\
\hline 1 & 0.000894 & 0.036435 & 0.281656 & 0.000018 & 0.281626 & -1.1 & 1.3 \\
\hline 2 & 0.000395 & 0.014240 & 0.281717 & 0.000033 & 0.281704 & 1.7 & 2.3 \\
\hline 3 & 0.000612 & 0.024240 & 0.281646 & 0.000018 & 0.281625 & -1.1 & 1.3 \\
\hline 4 & 0.001006 & 0.039610 & 0.281656 & 0.000015 & 0.281622 & -1.2 & 1.0 \\
\hline 5 & 0.000945 & 0.038300 & 0.281662 & 0.000019 & 0.281630 & -0.9 & 1.3 \\
\hline 6 & 0.001254 & 0.052530 & 0.281701 & 0.000021 & 0.281659 & 0.1 & 1.5 \\
\hline 7 & 0.000834 & 0.033040 & 0.281648 & 0.000015 & 0.281620 & -1.3 & 1.1 \\
\hline 8 & 0.001160 & 0.042100 & 0.281765 & 0.000031 & 0.281726 & 2.5 & 2.2 \\
\hline 9 & 0.001190 & 0.047900 & 0.281676 & 0.000017 & 0.281636 & -0.7 & 1.2 \\
\hline
\end{tabular}

Pavlyshyn, 2008; Vozniak et al., 2012), crystallized from fluids. Several pulses of $\mathrm{CO}_{2}$-rich fluids have been registered. Secondary inclusions in beryl contain $87 \mathrm{vol} \% \mathrm{CO}_{2}$ and 13 vol \% $\mathrm{CH}_{4}$ (Vozniak et al., 2012). Hydrocarbons can be derived either from basic melts during their degassing or from decomposition of organic matter that was found in several pegmatite bodies in the form of "kerite" (e.g. Gorlenko et al., 2000; Zhmur, 2003; Franz et al., 2017). Muscovite that occurs intimately intergrown with $\mathrm{NH}_{4}$-feldspar (buddingtonite) yielded a ${ }^{39} \mathrm{Ar} /{ }^{40} \mathrm{Ar}$ age of $1486 \pm 33 \mathrm{Ma}$ (Franz et al., 2021). As this age probably corresponds to the thermal event that was responsible for the muscovite 
formation, Franz et al. (2021) concluded that the age of $1486 \pm 33$ Ma represents a minimum age of the kerite formation, whereas the age of zircon crystallization $(1760 \pm 3 \mathrm{Ma})$ corresponds to the maximum age. Buddingtonite has yielded a ${ }^{39} \mathrm{Ar} /{ }^{40} \mathrm{Ar}$ age of $561 \pm 33 \mathrm{Ma}$, which can be explained by a weak re-heating of the area during the formation of the Volyn flood basalt province (Kuzmenkova et al., 2010; Shumlyanskyy et al. 2016). This figure defines the absolute minimum age of the microfossils responsible for the formation of organic matter in the Volyn chamber pegmatites (Franz et al., 2021).

\section{Conclusions}

New U-Pb data obtained for granites and pegmatites of the KPC confirm that the rock assemblage in its northern part belongs to the first pulse of magmatic activity between 1800 and $1780 \mathrm{Ma}$, whereas rocks in the southern part of the KPC intruded mainly between 1768 and 1755 Ma. Additionally, the first reliable U-Pb zircon ages for granites of the southwestern part of the KPC and for pegmatites of the Volyn pegmatite field indicate that granites were emplaced a few million years prior to the intrusion of the gabbro-anorthosite massif and that the chamber pegmatites crystallized coevally with the basic rocks. Field relationships indicate hybridization and mingling at the contacts between the basic rocks and granites and also that granites in a few-kilometre-wide band surrounding the younger basic intrusion experienced a significant influence from the basic melts in the form of the crystallization of ferrous olivine and clinopyroxene due to partial recrystallization and remobilization of interstitial melts. Ultimately, the formation of the chamber pegmatites was related to the secondary reheating of the semi-crystallized granitic intrusion and to the fluids migrating from the underlying gabbro-anorthosite massif.

Data availability. All the processed results are presented in the paper.

Author contributions. LS was responsible for the conceptualization of the research. LS, SG, OM, DV, and OB performed the field work and laboratory measurements. LS and GF coordinated the research. LS prepared the original draft. GF, SG, OM, and DV reviewed and edited the manuscript.

Competing interests. The contact author has declared that neither they nor their co-authors have any competing interests.

Disclaimer. Publisher's note: Copernicus Publications remains neutral with regard to jurisdictional claims in published maps and institutional affiliations.
Acknowledgements. We thank the Curtin Research Office for providing support to Leonid Shumlyanskyy. The paper has benefitted from constructive comments from Åke Johansson and one anonymous reviewer, as well as from associate editor Klaus Mezger. We also thank Frédéric Couffignal for his assistance in operating the 1280 HR instrument and Uwe Dittmann for preparing the SIMS sample mounts.

Financial support. This open-access publication was funded by Technische Universität Berlin.

Review statement. This paper was edited by Klaus Mezger and reviewed by Åke Johansson and one anonymous referee.

\section{References}

Afanasyev, A., Blundy, J., Melnik, O., and Sparks, R. S. J.: Formation of magmatic brine lenses via focused fluid-flow beneath volcanoes, Earth Planet. Sc. Lett., 486, 119-128, https://doi.org/10.1016/j.epsl.2018.01.013, 2018.

Amelin, Yu. V., Heaman, L. M., Verchogliad, V. M., and Skobelev, V. M.: Geochronological constraints on the emplacement history of an anorthosite-rapakivi granite suite: $\mathrm{U}-\mathrm{Pb}$ zircon and baddeleyite study of the Korosten complex, Ukraine, Contrib. Mineral. Petr., 116, 411-419, https://doi.org/10.1007/BF00310908, 1994.

Ashwal, L. D., Wiedenbeck, M., and Torsvik, T. H.: Archaean zircons in Miocene oceanic hotspot rocks establish ancient continental crust beneath Mauritius, Nature Com., 8, 14086, https://doi.org/10.1038/ncomms14086, 2017.

Baker, D. R. and Alletti, M.: Fluid saturation and volatile partitioning between melts and hydrous fluids in crustal magmatic systems: The contribution of experimental measurements and solubility models, Earth-Sci. Rev., 114, 298-324, https://doi.org/10.1016/j.earscirev.2012.06.005, 2012.

Black, L. P., Kamo, S. L., Allen, C. M., Davis, D. W., Aleinikoff, J. N., Valley, J. W., Mundil, R., Campbell, I. H., Korch, R. J., Williams, I. S., and Foudoulis, C.: Improved ${ }^{206} \mathrm{~Pb} /{ }^{238} \mathrm{U}$ microprobe geochronology by monitoring of a trace-element-related matrix effect; SHRIMP, IDTIMS, ELA-ICP-MS and oxygen isotope documentation for a series of zircon standards, Chem. Geol., 205, 115-140, https://doi.org/10.1016/j.chemgeo.2004.01.003, 2004.

Blundy, J. D., Mavrogenes, J., Tattitch, B., Sparks, R. S. J., and Gilmer, A.: Generation of porphyry copper deposits by gas-brine reaction in volcanic arcs, Nat. Geosci., 8, 235-240, https://doi.org/10.1038/ngeo2351, 2015.

Bogdanova, S. V., Pashkevich, I. K., Buryanov, V. B., Makarenko, I. B., Orlyuk, M. I., Skobelev, V. M., Starostenko, V. I., and Legostaeva, O. V.: The 1.80-1.74-Ga gabbro-anorthositerapakivi Korosten Pluton in the Ukrainian shield: a 3-D geophysical reconstruction of deep structure, Tectonophysics 381, 5-27, https://doi.org/10.1016/j.tecto.2003.10.023, 2004.

Bouvier, A., Vervoort, J. D., and Patchett, P. J.: The Lu-Hf and $\mathrm{Sm}-\mathrm{Nd}$ isotopic composition of CHUR: constraints from unequilibrated chondrites and implications for the bulk composi- 
tion of terrestrial planets, Earth Planet. Sc. Lett., 273, 48-57, https://doi.org/10.1016/j.epsl.2008.06.010, 2008.

Candela, P. A. and Blevin, P. L.: Do some miarolitic granites preserve evidence of magmatic volatile phase permeability?, Econ. Geol., 90, 2310-2316, https://doi.org/10.2113/gsecongeo.90.8.2310, 1995.

Capriolo, M., Marzoli, A., Aradi, L.E., Callegaro, S., Dal Corso, J., Newton, R. J., Mills, B. J. W., Wignall, P. B., Bartoli, O., Baker, D.R., Youbi, N., Remusat, L., Spiess, R., and Szabó, C.: Deep $\mathrm{CO}_{2}$ in the end-Triassic Central Atlantic Magmatic Province, Nature Com., 11, 1670, https://doi.org/10.1038/s41467-020-15325-6, 2020.

Chu, N.-C., Taylor, R. N., Chavagnac, V., Nesbitt, R. W., Boella, R. M., Milton, J. A., German, C. R., Bayon, G., and Burton, K.: $\mathrm{Hf}$ isotope ratio analysis using multi-collector inductively coupled plasma mass spectrometry: an evaluation of isobaric interference corrections, J. Anal. Atom. Spectrom., 17, 1567-1574, https://doi.org/10.1039/B206707B, 2002.

Duchesne, J.-C., Shumlyanskyy, L., and Mytrokhyn, O. V.: The jotunite of the Korosten Plutonic Complex (Ukrainian shield): crust- or mantle-derived?, Precambrian Res., 299, 5874, https://doi.org/10.1016/j.precamres.2017.07.018, 2017.

Franz, G., Khomenko, V., Vishnyevskyy, O., Wirth, R., Struck, U., Nissen, J., Gernert, U., and Rocholl A.: Biologically mediated crystallization of buddingtonite in the Paleoproterozoic: Organic-igneous interactions from the Volyn pegmatite, Ukraine, Am. Mineral., 102, 2119-2135, https://doi.org/10.2138/am2017-6055, 2017.

Franz, G., Sudo, M., and Khomenko, V.: ${ }^{40} \mathrm{Ar} /{ }^{39} \mathrm{Ar}$ dating of a hydrothermal pegmatitic buddingtonite-muscovite assemblage from Volyn, Ukraine, in revision, 2021.

Glynn, S. M., Master, S., Wiedenbeck, M., Davis, D. W., Kramers, J. D., Belyanin, G. A., Frei, D., and Oberthür, T.: The Proterozoic Choma-Kalomo Block, SE Zambia: Exotic terrane or a reworked segment of the Zimbabwe Craton?, Precambrian Res., 298, 421438, https://doi.org/10.1016/j.precamres.2017.06.020, 2017.

Gorlenko, V. M., Zhmur, S. I., Duda, V. I., Suzina, N. E., Osipov, G. A., and Dimitriev, V. V.: Fine structure of fossilized bacteria in Volyn kerite, Orig. Life Evol. Biosph., 30, 567-577, https://doi.org/10.1023/a:1026580615153, 2000.

Ivantyshyn, M. N., Klochkov, V. T., Lichak, I. L., Tsarovskiy, I. D., and Chemyshkova, L. P.: The piezoelectric quartz pegmatites of the Volyn area, Acad. Sci. of the Ukrainian SSR, 204 pp., 1957 (in Russian).

Kuzmenkova, O. F., Nosova, A. A., and Shumlyanskyy, L. V.: A comparison of the Neoproterozoic Volyn-Brest magmatic province with large continental flood basalt provinces of the world, the nature of low-Ti and high-Ti basic magmatism, Litasfera, 3-16, 2010 (in Russian).

Lazarenko, E. K., Pavlyshyn, V. I., Latysh, V. T., and Sorokin, Y. G.: Mineralogy and origin of chamber pegmatites of the Volyn region, Vyshcha Shkola publisher, Lviv, 360 pp., 1973 (in Russian)

Lichak, I. L.: Petrology of the Korosten pluton, Kyiv, Naukova Dumka publisher, 247 pp., 1983 (in Russian).

Lichak, I. L. and Tsarovskiy, I. D.: The structure of the pegmatite field (pegmatite localization and pegmatite zones), in: Pegmatites of the Volyn region, Kyiv, Acad. Sci. publisher, 1957 (in Russian).
Ludwig, K. R.: Isoplot/Ex version 3.75: A Geochronological Toolkit for Microsoft Excel, Berkeley Geochron. Center, Spec. Publ. 5, 75 pp., 2012.

Lyckberg, P., Chernousenko, V., and Wilson, W. E.: Famous mineral localities: Volodarsk-Volynski, Zhitomir Oblast, Ukraine, Mineral. Record, 40, 473-506, 2009.

Lyckberg, P., Chournousenko, V., and Chournousenko, O.: Giant heliodor and topaz pockets of the Volodarsk chamber pegmatites, Korosten pluton, Ukraine, Abs. vol. Int. gemmological Conf. Nantes - France, August 2019, 78-83, 2019.

Marakushev, A. A., Gramenitskiy, Ye. N., and Lukashev, A. N.: Layering of the Korosten pluton and the occurrence of pegmatites, Int. Geol. Rev., 31, 556-573, https://doi.org/10.1080/00206818909465908, 1989.

Masotta, M., Gaeta, M., Gozzi, F., Marra, F., Palladino, D., and Sottili, $\mathrm{G} .: \mathrm{H}_{2} \mathrm{O}^{-}$and temperature-zoning in magma chambers: The example of the Tufo Giallo della Via Tiberina eruptions (Sabatini Volcanic District, central Italy), Lithos, 118, 119-130, https://doi.org/10.1016/j.lithos.2010.04.004, 2010.

Mitrokhin, O. V. and Bilan, E. V.: Petrology of the "hybrid rocks" of the Korosten Pluton of the anorthosite-rapakivi granite association of the Ukrainian Shield, Mineral. J. Ukraine, 36, 102-118, 2014 (in Russian).

Mitrokhin, A. V., Bogdanova, S. V., and Shumlyanskyy, L. V.: Polybaric crystallization of anorthosite of the Korosten pluton, Ukrainian shield, Mineral. J. Ukraine, 30, 36-56, 2008 (in Russian).

Patchett, P. and Tatsumoto, M.: Lu-Hf total-rock isochron for the eucrite meteorites, Nature, 288, p. 571, https://doi.org/10.1038/288571a0, 1980.

Peretyazhko, I. S.: Genesis of mineralized cavities (miaroles) in granitic pegmatites and granites, Petrology, 18, 183-208, https://doi.org/10.1134/S0869591110020062, 2010.

Phelps, P. R., Lee, C. T. A., and Morton, D. M.: Episodes of fast crystal growth in pegmatites, Nature Com., 11, 4986, https://doi.org/10.1038/s41467-020-18806-w, 2020.

Pistone, M., Baumgartner, L. P., Bégué, F., Jarvis, P. A., Bloch, E., Robyr, M., Müntener, O., Sisson, T. W., and Blundy, J. D.: Felsic melt and gas mobilization during magma solidification:an experimental study at $1.1 \mathrm{kbar}$, Front. Earth Sci., 8, 175, https://doi.org/10.3389/feart.2020.00175, 2020.

Shcherbak, M. P., Artemenko, G. V., Lesnaya, I. M., Ponomarenko, A. N., and Shumlyanskyy, L. V.: Geochronology of the Early Precambrian of the Ukrainian shield. Proterozoic, Naukova dumka publisher, Kyiv, 240 pp., 2008 (in Russian).

Shishkina, T. A., Botcharnikov, R. E., Holtz, F., Almeev, R. R, Jazwa, A. M., and Jakubiak, A. A.: Compositional and pressure effects on the solubility of $\mathrm{H}_{2} \mathrm{O}$ and $\mathrm{CO}_{2}$ in mafic melts, Chem. Geol., 388, 112-129, https://doi.org/10.1016/j.chemgeo.2014.09.001, 2014.

Shumlyanskyy, L. V. and Bogdanova, S. V.: U-Pb age of zircons and geochemistry of rhyolites of the Ovruch depression, NorthWestern region of the Ukrainian shield, Mineral. J. Ukraine, 31, 40-49, 2009 (in Ukrainian).

Shumlyanskyy, L. V. and Mazur, M. D.: Age and composition of jotunites of the Bilokorovychi dyke swarm, Geol. Ukraine, 1-2, 70-78, 2010 (in Ukrainian).

Shumlyanskyy, L. V. and Zahnitko, V. M.: Isotope age, geochemistry, and mineralogy of pegmatites in anorthosites of the 
Volodarsk-Volynsky massif, Korosten plutonic complex, Mineral. J. Ukraine, 33, 15-29, 2011 (in Ukrainian).

Shumlyanskyy, L., Ellam, R. M., and Mitrokhin, O.: The origin of basic rocks of the Korosten AMCG complex, Ukrainian shield: implication of $\mathrm{Nd}$ and $\mathrm{Sr}$ isotope data, Lithos, 90, 214-222, https://doi.org/10.1016/j.lithos.2006.03.004, 2006.

Shumlyanskyy, L., Ernst, R., and Billström, K.: A U-Pb baddeleyite age of the Davydky gabbro-syenite massif of the Korosten plutonic complex, Geochem. Ore Formation, 35, 37-42, $2015 \mathrm{a}$.

Shumlyanskyy, L., Hawkesworth, C., Dhuime, B., Billström, K., Claesson, S., and Storey, C.: ${ }^{207} \mathrm{~Pb} /{ }^{206} \mathrm{~Pb}$ ages and $\mathrm{Hf}$ isotope composition of zircons from sedimentary rocks of the Ukrainian shield: crustal growth of the south-western part of East European craton from Archaean to Neoproterozoic, Precambrian Res., 260, 39-54, https://doi.org/10.1016/j.precamres.2015.01.007, 2015b.

Shumlyanskyy, L., Nosova, A., Billström, K., Söderlund, U., Andréasson, P.-G., and Kuzmenkova, O.: The U-Pb zircon and baddeleyite ages of the Neoproterozoic Volyn Large Igneous Province: implication for the age of the magmatism and the nature of a crustal contaminant, GFF, 138, 17-30, https://doi.org/10.1080/11035897.2015.1123289, 2016.

Shumlyanskyy, L., Hawkesworth, C., Billström, K., Bogdanova, S., Mytrokhyn, O., Romer, R., Dhuime, B., Claesson, S., Ernst, R., Whitehouse, M., and Bilan, O.: The origin of the Palaeoproterozoic AMCG complexes in the Ukrainian Shield: new U-Pb ages and Hf isotopes in zircon, Precambrian Res., 292, 216-239, https://doi.org/10.1016/j.precamres.2017.02.009, 2017.

Shumlyanskyy, L. V., Mytrokhyn, O. V., Duchesne, J.-C., Bogdanova, S. V., Billström, K., Omelchenko, A. N., and Bagiński, B.: Petrology of subalkaline dolerite dykes of the Korosten Complex, the North-Western region of the Ukrainian Shield, Mineral. J. Ukraine, 40, 32-52, https://doi.org/10.15407/mineraljournal.40.01.032, 2018a (in Russian).

Shumlyanskyy, L. V., Stepanyuk, L. M., Claesson, S., Rudenko, K. V., and Bekker, A. Y.: The U-Pb zircon and monazite geochronology of granitoids of the Zhytomyr and Sheremetiv complexes, the Northwestern region of the Ukrainian Shield, Mineral. J. Ukraine, 40, 63-85, https://doi.org/10.15407/mineraljournal.40.02.063, 2018b (in Ukrainian).

Sisson, T. W. and Bacon, C. R.: Gas-driven filter pressing in magmas, Geology, 27, 613-616, https://doi.org/10.1130/00917613(1999)027<0613:GDFPIM>2.3.CO;2, 1999.

Sobolev, V. S.: Petrology of the eastern part of the complex Korosten pluton, Sci. proc. Lviv. University, Series Geol., 5, 128 pp., 1947 (in Russian).

Söderlund, U., Patchett, J. P., Vervoort, J. D., and Isachsen, C. E.: The ${ }^{176} \mathrm{Lu}$ decay constant determined by Lu-Hf and U$\mathrm{Pb}$ isotope systematics of Precambrian mafic intrusions, Earth Planet. Sc. Lett., 219, 311-324, https://doi.org/10.1016/S0012821X(04)00012-3, 2004.
Stacey, J. S. and Kramers, J. D.: Approximation of terrestrial lead isotope evolution by a two-stage model, Earth Planet. Sc. Let., 26, 207-221, https://doi.org/10.1016/0012821X(75)90088-6, 1975.

Steiger, R. H. and Jäger, E.: Subcommission on geochronology: convention on the use of decay constants in geoand cosmochronology, Earth Planet. Sc. Let., 36, 359-362, https://doi.org/10.1016/0012-821X(77)90060-7, 1977.

Stepanyuk, L. M., Yesypchuk, K. Yu., Boychenko, S. O., Skobelev, V. M., Dovbush, T. I., and Shcherbak, D. M.: On the age of granite formation in the basins of Teteriv and Irpin rivers, Mineral. J. Ukraine, 22, 115-118, 2000 (in Ukrainian).

Tarasenko, V. E.: On rocks of the gabbro family from Radomyshl and Zhytomyr regions of the Kyiv province, 1895 (in Russian).

Thomas, R., Davidson, P., Rhede, D., and Leh, M.: The miarolitic pegmatites from the Königshain: a contribution to understanding the genesis of pegmatites, Contrib. Mineral. Petr., 157, 505-523, https://doi.org/10.1007/s00410-008-0349-2, 2009.

Vigneresse, J. L.: Textures and melt-crystal-gas interactions in granites, Geosci. Front., 6, 635-663, https://doi.org/10.1016/j.gsf.2014.12.004, 2015.

Vozniak, D. K.: Microinclusions and reconstructions of the conditions of endogenous formation of minerals, Naukova Dumka publisher, Kyiv, 280 pp., 2007 (in Ukrainian).

Vozniak, D. K. and Pavlyshyn, V. I.: Physico-chemical conditions of formation and peculiarities of localization of chamber pegmatites of Volyn (the Ukrainian Shield), Mineral. J. Ukraine, 30, 5-20, 2008 (in Ukrainian).

Vozniak, D. K., Khomenko, V. M., Franz, G., and Wiedenbeck, M.: Physico-chemical conditions of the late stage of Volyn pegmatite evolution: Fluid inclusions in beryl studied by thermobarometry and IR-spectroscopy methods, Mineral. J. Ukraine, 34, 26-38, 2012 (in Ukranian).

Wiedenbeck, M., Allé, P., Corfu, F., Griffin, W. L., Meier, M., Oberli, F., Von Quadt, A., Roddick, J. C., and Spiegel, W.: Three natural zircon standards for U-Th- $\mathrm{Pb}, \mathrm{Lu}-\mathrm{Hf}$, trace element and REE analysis, Geostandard Newslett., 19, 1-23, https://doi.org/10.1111/j.1751-908X.1995.tb00147.x, 1995.

Woodhead, J., Hergt, J., Shelley, M., Eggins, S., Kemp, R.: Zircon Hf isotope analysis with an excimer laser, depth profiling, ablation of complex geometries, and concomitant age estimation, Chem. Geol., 209, 121-135, https://doi.org/10.1016/j.chemgeo.2004.04.026, 2004.

Zhmur, S. I.: Origin of Cambrian fibrous kerites of the Volyn region, Lithol. Mineral Resour., 38, 55-73, https://doi.org/10.1023/A:1021827724818, 2003.

Zito, G. and Hanson, S. L.: Minerals from the miarolitic pegmatites in the Stove Mountain Area, Colorado Springs, Colorado, Rocks Miner., 89, 224-237, https://doi.org/10.1080/00357529.2014.878181, 2014. 